\title{
Los límites a la autonomía de la Fiscalía en la adecuación típica de la conducta punible*
}

\author{
Diana Karina Pineda-Castro**
}

\section{Resumen}

El trabajo está orientado a resolver si el juez de control de garantías puede obligar al fiscal a realizar una variación de la imputación jurídica, cuando la misma vulnera el principio de legalidad. Sobre ello se han planteado diversas posturas: en lo que atañe a la denominación jurídica de los hechos, no resulta acertado entender que el fiscal -pese a estar demostrada una determinada configuración típica- cuente con amplias facultades para negociarla con el procesado, toda vez que el principio de legalidad le impone un límite mucho más restringido. Por el contrario, para cierta parte de la doctrina y la jurisprudencia, debe acatarse en debida forma, la concepción del sistema penal con tendencia acusatoria, pues se sostiene que no es del resorte de los jueces ejercer la acción penal; así, tratándose de los alcances y límites de la imputación, esta debe ser meramente fáctica y estar desprovista de consideraciones jurídicas, por lo que el papel del juez sería absolutamente pasivo, el de un simple instrumento a través del cual se formaliza la imputación y asumir una actitud contraria conllevaría una intromisión en la función de investigación asignada a la Fiscalía. Las reflexiones ulteriores se ocupan del análisis de tales alternativas y, al final, se toma posición.

\section{Palabras clave}

Acción penal, principio acusatorio, principio de legalidad, principio de taxatividad, derechos de las víctimas, debido proceso, verdad y justicia, adecuación típica de la conducta.

\footnotetext{
"Artículo de reflexión resultado del trabajo de grado para optar al título de magíster en Derecho, Línea de Investigación en Derecho Procesal Penal, Universidad Sergio Arboleda, Bogotá (Colombia), dirigido por el profesor Jorge A. Abello Gual.

${ }^{*}$ Magíster en Derecho, Línea de Investigación en Derecho Procesal Penal, Universidad Sergio Arboleda.
} 


\title{
The Limits on the Autonomy of the Prosecution in the Typical Adequacy of the Criminal Offense
}

\begin{abstract}
The article is aimed to solve the problem if the guarantees control judge may force the prosecutor to make a change in the legal complaint when it violates the principle of legality. Various positions have been raised on this : as regards the legal designation of the facts, it is not wise to understand that the prosecutor - in spite of the fact that a particular typical configuration has been shown - counts with broad powers to negotiate with the defendant, since the rule of law imposes a much narrower limit. On the contrary, for some part of the doctrine and jurisprudence, it must be complied in due form, with the conception of the accusatory trend of the penal system, as it argues that it is not a faculty of the judges to conduct the criminal investigation; and, in the case of the scope and limits of the complaint, this must be purely factual and devoid of legal considerations, so the role of the judge would be absolutely passive, that of a mere instrument through which the complaint is formalized and taking a contrary attitude would lead to ian nterference in the investigation functions assigned to the prosecution. Subsequent reflections are dealing with the analysis of such alternatives and in the end a position is taken.
\end{abstract}

\section{Keywords}

Criminal proceedings, adversarial principle, principle of legality, principle of taxativity victims' rights, due process, truth and justice, typical appropriateness of behavior. 


\section{Introducción}

El problema jurídico que pretende resolver este trabajo consiste en establecer si el juez de control garantías puede-y debe-intervenir en la imputación formulada por la Fiscalía cuando aquella vulnera el principio de legalidad. Este asunto también preocupa a los sistemas de justicia penal en varios países que han enfrentado cambios de diversa naturaleza; América Latina, por supuesto, no escapa a esa transformación ni a las dificultades que apareja su introducción.

Lo anterior, en la medida en que, desde hace varias décadas, se han puesto en duda las bases del denominado modelo inquisitivo, propio de un larga tradición, en el cual se fundamentaban los diversos sistemas procesales penales y se han establecido unos modelos con tendencia acusatoria y adversarial, como ocurrió en Chile, Alemania, Portugal, España, Italia, Puerto Rico, Colombia, Perú, Costa Rica, Argentina, entre otros. A los efectos de esta trabajo interesa estudiar, especialmente, lo atinente a la potestad de la Fiscalía General de la Nación, en cuanto titular de la acción penal, de imputar conductas a quienes considera que son sus posibles autores o partícipes y la consecuente facultad que le asiste a dicho órgano de adecuar los comportamientos que lesionan bienes jurídicamente tutelados a los diversos tipos penales consignados en la ley penal sustantiva.

Ello es de suma importancia, porque la praxis judicial evidencia que, en no pocos casos, el ente acusador no es coherente a la hora de formular las correspondientes imputaciones en relación con las circunstancias de tiempo, modo y lugar en que ocurre un hecho, e incluso con la denominación jurídica que se le atribuye al mismo. Así, por ejemplo, un homicidio cometido en circunstancias de agravación como la sevicia o el estado de indefensión de la víctima es imputado en la modalidad de simple y no se le da la connotación de agravado; esa omisión, como se analiza luego, vulnera los derechos de las víctimas a la verdad y a la justicia sin dejar de lado, además, las afectaciones al principio de legalidad, como componente esencial del debido proceso contemplado en el artículo 29 del Estatuto Superior.

La pertinencia del problema apuntado radica en que la legislación procesal penal vigente no define con claridad los límites que tiene la Fiscalía al momento de realizar la adecuación típica de la conducta que se presume delictiva, amén de que-teniendo aquella la potestad exclusiva de acusar- puede quedar a su arbitrio la denominación 
jurídica de los comportamientos, al menos en la audiencia preliminar de formulación de imputación, pues, por tratarse de un acto de simple comunicación inherente a dicho ente-según se ha dicho-, el juez de control de garantías no puede interferir de manera directa.

Esa ausencia de control al acto de imputación en los términos explicados anteriormente, puede comportar que en la etapa de juzgamiento se generen eventuales nulidades por desconocimiento del principio de taxatividad, como elemento integrante del postulado de legalidad. Igualmente, ante la rigidez de la ley procesal penal existente, también se le niega al Ministerio Público -como garante del respeto al ordenamiento jurídico- y a las propias víctimas la posibilidad de pronunciarse sobre la imputación jurídica que hace la Fiscalía y que puede afectar al orden jurídico o a sus intereses, especialmente cuando existe falta de consonancia entre el acontecer fáctico y la denominación jurídica dada al hecho en la imputación. De esta manera, pues, se pueden ver vulnerados sus derechos a la verdad y a la justicia.

Por ello, el objetivo principal de esta incursión académica es determinar si existe la necesidad de que la Fiscalía, a solicitud del juez o de las partes, varíe la imputación jurídica cuando esta vulnera el principio de legalidad. Además, se persiguen los siguientes objetivos específicos: establecer el alcance y la finalidad del principio acusatorio en Colombia y en otras legislaciones; analizar la acusación como potestad exclusiva de la Fiscalía al tenor de lo establecido en el canon 250 constitucional; y, añádase, se explican las razones por las cuales se considera que la Fiscalía, como titular de la acción penal, no puede desconocer el principio de taxatividad o de determinación al momento de efectuar la calificación jurídica de la conducta punible.

Respecto a la metodología adoptada, debe decirse que la investigación es de tipo descriptivo en la medida en que se fundamenta en principios teóricos como los propios de la hermenéutica, empleando, además, métodos de recolección cualitativos, con el propósito de explorar los axiomas que rigen en un sistema penal de naturaleza acusatoria con miras a demostrar la tesis de que, si bien la Fiscalía es la titular de la acción penal, la autonomía de que goza al momento de adecuar los comportamientos que se presumen delictivos no es absoluta sino que encuentra límites, especialmente, en los derechos de las víctimas a la verdad y a la justicia (Corte Constitucional, sentencia C-209 de 2007). 
Igualmente, en armonía con lo anterior, se busca evidenciar que en el sistema procesal penal colombiano sí resulta necesario, en virtud del control de legalidad que le asiste al juez, que este, como director del proceso, pueda sugerir la modificación de la calificación jurídica de los hechos. Con estas miras, pues, luego de abordar el asunto objeto de indagación en el ámbito del derecho comparado (la imputación desde la perspectiva del sistema de tendencia acusatoria) se aterriza el debate a lo ocurrido en Colombia, a cuyo efecto se examinan los alcances del principio acusatorio en el derecho positivo. Además, se estudian los pormenores de la variación de la imputación jurídica a solicitud del juez de garantías cuando se desconoce el principio de taxatividad; $y$, al final, se consignan las conclusiones de este ejercicio académico y el material consultado.

\section{El principio acusatorio y la imputación en algunos países}

El principal obstáculo teórico para que los jueces objeten la denominación jurídica dada a la conducta por la Fiscalía en las diferentes instancias de un proceso penal, es el principio acusatorio entendido, en parte, como la facultad exclusiva de la Fiscalía General de la Nación para iniciar la acción penal, amén de la necesidad de que las funciones de investigar y de juzgar se encuentren en órganos diferentes. De acuerdo con dicha perspectiva de análisis, se ha establecido desde la Constitución y la ley procesal penal que, para garantizar la imparcialidad del juez, la acción penal debe ser una función exclusiva de la Fiscalía General de la Nación y que los jueces, en principio, solo deben limitarse a verificar los requisitos formales de los actos y la protección de los derechos de los procesados, sin tener facultades para revisar ni solicitar la variación de la calificación jurídica de los mismos, so pena de vulnerar el principio acusatorio, y, en consecuencia, de afectar su imparcialidad a lo largo del proceso.

La problemática generada por dicha postura, que limita de manera radical cualquier posibilidad de revisión material sobre la calificación jurídica que haga de los hechos la Fiscalía, ha suscitado muchas discusiones importantes respecto del contenido y el alcance del principio acusatorio, porque la posibilidad de que el juez pueda corregir errores en la calificación jurídica, para proteger las garantías procesales y, especialmente, el principio de legalidad y los derechos fundamentales del procesado y de las víctimas, parece ser una exigencia casi que inevitable para un juez que ejerce la función de control de garantías en un Estado social y democrático de derecho. 
No resulta apropiado, desde esta perspectiva, que ante una evidente violación al principio de legalidad en materia penal, un juez tenga que permanecer inactivo y sumiso ante las actuaciones realizadas por la Fiscalía en un proceso penal, por el mero respeto a los dictados del principio acusatorio. Por ello, en la doctrina española se considera que el principio acusatorio sólo sería un postulado judicial, o de conformación orgánica, y no procesal o procedimental, puesto que contribuye a garantizar la imparcialidad del juzgador (Gómez, 2007, p. 50).

Gómez (2007), luego de hacer alusión a diversos argumentos por los cuales estima que el concepto apuntado suele confundirse con el de sistema acusatorio, señala que por principio acusatorio debe entenderse únicamente que acusador y juzgador no pueden ser la misma persona y que los hechos y las pruebas sólo deben aportarse por las partes (ministerio fiscal y defensa) -aspecto sobre el cual se centra verdaderamente la confusión en España-, con la finalidad de reforzar la posición del tercero encargado de decidir el asunto, es decir, la imparcialidad del juez, pues, en definitiva, se estaría frente a un principio de configuración judicial -orgánica- y no procesal.

Por ello, entiende que el principio acusatorio es un concepto poco claro, producto de la confusión histórica que se produce al calificar como acusatorio a todo un sistema de aplicar el derecho penal enfrentado a otro modelo que sería el denominado inquisitivo. Sin embargo, el proceso únicamente puede ser acusatorio, por lo que la discusión caería en el vacío, razón por la cual opta por admitir la expresión 'principio acusatorio' pero entendida en un sentido muy estricto: principio acusatorio es aquel que en el proceso penal está encargado de garantizar la imparcialidad del juzgador (Gómez, 2007, p. 15). Semejante es el pensamiento de Montero (1994, p. 530), para quien solo se puede llamar proceso al proceso acusatorio, en el que es de la esencia la presencia del juez imparcial y de las partes enfrentadas entre sí. Así las cosas, la expresión principio acusatorio ha de entenderse solo bajo estos tres significados: (a) que no pueda existir proceso sin acusación, la cual debe ser formulada por persona distinta a quien va a juzgar; (b) que no proceda condena por hechos distintos de los vislumbrados en la acusación, ni contra persona distinta de la acusada; y (c) que el juez no pueda tener facultades de dirección material del proceso, por tanto, le estaría vedado aportar hechos o decretar pruebas de oficio, debiendo ser en todo caso un tercero imparcial (Gómez, 2007, p. 4). 
El principio acusatorio se erige como uno de los postulados orientadores del proceso acusatorio que regula aspectos bien específicos del mismo, cuyo contenido se ciñe a la separación de la función de acusación de la de enjuiciamiento, funciones que deben ser atribuidas a órganos distintos, y por tal motivo la acusación el objeto del proceso- debe ser planteada en juicio por un sujeto distinto del juez (Rodríguez, 2013, p. 647).

No muy distantes son los planteamientos de Horvitz y López (2002, p. 43), para quienes el principio acusatorio impone la distribución de los poderes de persecución penal y, consecuente con ello, de las funciones inherentes a su ejercicio, implicando una triple separación entre las funciones de investigación, acusación y enjuiciamiento, motivo por el cual son enfáticos al afirmar que dicho postulado puede descomponerse en dos aspectos esenciales: distribución de las funciones de acusación y decisión y distribución de las funciones de investigación y decisión. El primero, exige la presencia de un acusador que sostiene la acusación y de un juez que decide respecto de la misma; en tanto que, el segundo, conlleva la efectividad de la garantía a ser juzgado por un tribunal independiente e imparcial. Por ello, se concluye que la incorporación del principio acusatorio al sistema procesal penal chileno es, sin lugar a dudas, el aspecto más característico y valioso de la reciente reforma.

Si bien es claro en los apartes anteriores cuáles son las notas más características de un sistema procesal penal con tendencia acusatoria, lo cierto es que en la práctica varios países han introducido algunos ajustes que no responden a sus rasgos característicos, entre ellos los relativos a los controles que deben ejercer los jueces sobre las competencias del ente acusador, en punto de lo cual se han intentado varias fórmulas. En España, por ejemplo, el artículo 622 de la Ley de Enjuiciamiento Criminal dispone que, cuando se hayan practicado las diligencias decretadas de oficio o a instancia del juez instructor, si este considerase terminado el sumario, lo declarará así, mandando remitir los autos y las piezas de convicción al Tribunal competente para conocer del delito.

Con ello se sigue el principio de acuerdo con el cual solamente se llevará a juicio a una persona cuando existan suficientes elementos para ello. De ahí que para autores como Montero (1994, p. 534), la etapa de investigación cumple en esencia dos finalidades: la preparación del juicio, en primer término, y la evitación de juicios inútiles, en el segundo. Señala además la norma en cita que cuando 
no haya acusador privado y el Ministerio Fiscal considere que en el sumario se han reunido los suficientes elementos para hacer la calificación de los hechos y poder entrar en los trámites del juicio oral, lo hará presente al juez de instrucción para que, sin más dilaciones, se remita lo actuado al tribunal competente.

De acuerdo con ello, en España, el juez de instrucción criminal -que cumple unas funciones distintas a la del Juez de control de garantías en el sistema colombiano- es un filtro que revisa si existe suficiente mérito para iniciar un juicio contra una persona. Aquí, entonces, el juez tiene más influencia en el proceso al analizar de fondo la causa penal, y el decreto del archivo del proceso, sin que por ello se pueda desvirtuar el principio acusatorio en el proceso penal español que, en todo caso, se garantiza con el Ministerio Fiscal (también muy distinto a la Fiscalía colombiana) en el juicio. De esta manera, el legislador español optó por permitir una mayor participación del juez en el análisis de la actuación del fiscal en pro de asegurar que no se inicien juicios penales en contra de personas, sin el suficiente sustento.

En Italia, por su parte, el Ministerio Fiscal es igualmente quien detenta el monopolio de la acción penal como se infiere de los artículos 50, 405 y 416 del Código de Procedimiento Penal, y por ello, ostenta facultades respecto de la instrucción del proceso y la definición de las medidas alternativas a la persecución penal (artículos 444 y siguientes del Código de Procedimiento Penal). Se cuenta allí, además, con la figura del Juez de las Investigaciones Preliminares (Gómez, 1997, p. 339). De la misma forma, el referente constitucional por excelencia del proceso penal en Italia deviene del artículo 111 Superior, que describe los componentes del proceso justo (debido proceso). De esta norma se desprende la regulación contenida en el Código de Procedimiento Penal, "el órgano titular de la acción penal que da inicio al procedimiento es el Ministerio Público. El juez fija la audiencia preliminar" (Caso, 2003, p. 2). Así las cosas, después de esta audiencia preliminar tiene lugar la fase de investigación, y, si el Ministerio Público encuentra que existe suficiente material probatorio en contra del inculpado, solicita al juez que se llame a juicio al acusado, y formula la imputación.

Es llamativo en el sistema procesal penal italiano el poder del juez de la audiencia preliminar, quien puede ordenar al Ministerio Público, si considera que sus averiguaciones están incompletas, que realice las indagaciones a que haya lugar, "o puede disponer, 
incluso de oficio, la asunción de las pruebas que indiquen de forma decisiva la necesidad de sentencia de cesación de procedimiento" (Caso, 2003, p. 9). Además, en el transcurso de esta audiencia preliminar, el Ministerio Público tiene la posibilidad de modificar la imputación. Desde esta perspectiva, pues, el proceso penal italiano es otro ejemplo en el cual un juez puede intervenir en la imputación que haga la Fiscalía, dado que, como se menciona, el fundamento de esta intervención también es el de asegurar que no se inicien los juicios sin suficiente sustento, incluso, dándole al juez la facultad de modificar la imputación.

A su turno, en Portugal, el fiscal es titular de la acción pública penal como se infiere del artículo 241 del Código de Procedimiento Penal, por lo que la fase de investigación es de su competencia, previéndose además un conjunto de medidas alternativas a la persecución penal (artículos 281 y siguientes). Asimismo, el fiscal también cuenta con funciones de ejecución penal como lo revela el artículo 469 del Código de Procedimiento Penal (Gómez, 1997, p. 339). En el sistema procesal penal portugués, se cuenta con una etapa de investigación preliminar, a la que se sigue la instrucción preparatoria, con la finalidad de establecer la materialidad del delito y la probable responsabilidad penal del infractor (Pinto, 1988, p. 59). Además, ese sistema jurídico dispone de un procedimiento penal abreviado que tiene como institución característica la realización de una audiencia oral y contradictoria, que se denomina debate instrutório, trámite que puede ser solicitado por la persona sometida a la potestad punitiva en un plazo que se cuenta desde la notificación de la acusación. Por ello se afirma que "la audiencia tendrá por finalidad determinar si los elementos de convicción existentes son suficientes para justificar el sometimiento del justiciable a juicio" (Maciel, 2003, p. 428). De esta manera, ese procedimiento es otro ejemplo en el que se admite que el juez participe en la imputación para garantizar que no se inicie un juicio sin suficiente sustento, creando un filtro previo antes del juicio.

En el contexto latinoamericano, puede comenzar hablándose de la legislación procesal chilena que implantó un sistema acusatorio a partir de la promulgación del Código Procesal Penal en el año 2000, pues, con antelación a ello, regía uno de carácter inquisitivo contenido en el Estatuto Procesal Penal de 1906 (Obando, 1999, pp. 31-39). Por ello, en virtud del principio acusatorio, el órgano jurisdiccional sólo puede intervenir en un asunto penal cuando se le 
ha sometido a su conocimiento a través de una acusación; es por eso que encuentra plena justificación el axioma: si no hay acusador no hay juez (Castro, 2005, p. 345).

Los artículos 80A de la Constitución Política de la República de Chile y $1^{\circ}$ de la Ley Orgánica Constitucional del Ministerio Público (LOCMP, 1999), prevén que dicho ente dirigirá en forma exclusiva la investigación de los hechos constitutivos de delito, los que determinen la participación punible y los que acrediten la inocencia del imputado y, en su caso, ejercerá la acción penal pública en la forma prevista por la ley. Tales normativas deben analizarse de manera armónica con el canon 77 del Código Procesal Penal Chileno, el cual establece que:

[1]os fiscales ejercerán y sustentarán la acción penal pública en la forma prevista por la ley. Con ese propósito practicarán todas las diligencias que fueren conducentes al éxito de la investigación y dirigirán la actuación de la policía, con estricta sujeción al principio de objetividad consagrado en la Ley Orgánica Constitucional del Ministerio Público (Código Procesal Penal de la República de Chile, 2000).

De esta manera, se logró que las funciones de investigar y acusar fueran entregadas a un organismo autónomo denominado Ministerio Público, en tanto que la función de decidir fue atribuida a un órgano jurisdiccional colegiado integrado por tres jueces denominado tribunal de juicio oral en lo penal. Además, la función de controlar el respeto por las garantías individuales durante la etapa de investigación, así como en Colombia, fue encomendada por la ley al juez de garantía, tribunal unipersonal distinto del encargado de dirimir la controversia (Horvitz y López, 2002, p. 45). Ahora bien, en lo que mira con la estructura del acto de imputación, en el ordenamiento chileno se tiene que ella se enmarca en la etapa de formalización de la investigación, que se consigue cuando, frente al juez de garantía, el Ministerio Público le comunica al imputado que está adelantando una investigación por hechos que constituyen delito; esta formalización de la investigación no constituye acusación (Gobierno de Chile, Ministerio de Justicia, 2005, p. 4).

La referida formalización de la investigación se lleva a cabo en audiencia, donde tendrá lugar el aludido acto de comunicación "para que el fiscal ponga en conocimiento del imputado, en presencia del Juez de Garantía, la circunstancia de estar llevando adelante una 
investigación en su contra por uno o más delitos determinados" (Gobierno de Chile, Ministerio de Justicia, 2005, p. 19). En esta etapa de cierre de la investigación en el proceso penal chileno, a diferencia de lo establecido en el estatuto procesal penal colombiano, se contempló en el artículo 232 la necesidad de que el fiscal exponga verbalmente los cargos que presenta contra el imputado y las demás solicitudes que procedan ante el juez, concediéndosele la oportunidad al investigado de manifestar aquello que considere pertinente. Con lo previsto en esta disposición, como es obvio, se abre la posibilidad de introducir un verdadero sistema penal de corte acusatorio en el modelo chileno porque se posibilita un debate jurídico entre las partes sobre los cargos imputados.

Y respecto del control que el juez de garantía debe efectuar sobre la imputación, algún sector de la doctrina refiere que sus posibilidades exceden el mero control formal para indicar que se trataría, entonces, de: (i) un control de legalidad fuerte, que exige de parte del juez un pronunciamiento que conlleve una opinión jurídica propia sobre el fondo de la calificación jurídica, o (ii) se trata de verificar la razonabilidad jurídica de la calificación de los hechos, o de comprobar la existencia de un "piso jurídico sensato" (Mera-Figueroa, 2002, p. 240). Para quienes afirman lo anterior, debe hallarse un equilibrio entre las actuaciones iniciales del procedimiento y el criterio de plausibilidad jurídica de la calificación realizada por el Ministerio Público, y, en tal sentido, no puede perderse de vista que la función del juez de control, no es la resolución del fondo del asunto, sino la verificación de la plausibilidad jurídica de la solicitud del fiscal.

En cuanto a la imputación, el artículo 390 del Código Procesal Penal chileno establece que, una vez recibida por el fiscal la denuncia de un hecho constitutivo de alguno de los delitos a que alude el canon 388 del mismo estatuto, aquél solicita al juez de garantía competente la citación inmediata a audiencia, a menos que sean insuficientes los antecedentes allegados. Este procedimiento, al igual que en Colombia, debe contener unos requisitos, entre otros, la individualización del imputado, una relación sucinta del hecho que se le atribuye y sus circunstancias relevantes, la disposición legal infringida, los elementos que fundamentan la imputación y la pena solicitada por el requirente.

De acuerdo con lo anterior, de cara al ordenamiento jurídico procesal chileno, que es muy parecido al nuestro, es igualmente pertinente la cuestión planteada en este trabajo sobre la necesidad de 
que exista un debate en el acto de imputación relativo a la calificación jurídica que haga el ente acusador de los hechos imputados, ya no frente a la garantía de no iniciar juicios sin suficiente soporte, sino frente a la garantía del principio de legalidad y la función del juez de control de garantías, donde se evidencia que, de existir este control legal sobre la calificación jurídica que haga el ente acusador, no afectaría en nada el proceso.

Ahora bien, en la República de Argentina, la característica fundamental del enjuiciamiento acusatorio radica en la división de los poderes que se ejercen en el proceso: de una parte, el acusador, quien persigue penalmente $\mathrm{y}$ ejerce el poder requirente $\mathrm{y}$, de otra, el imputado, quien tiene la facultad de resistir la imputación ejerciendo los derechos de defensa y contradicción, sin dejar de lado al tribunal, el cual tiene en sus manos el poder de decidir el fondo del asunto (Maier, 1989, p. 207). Por ello, la doctrina ha planteado la necesidad de que se introduzca la separación funcional entre acusación y juzgamiento a la luz de un postulado que ilumina la normativa procesal argentina. De acuerdo con Maier (1989), la actividad acusatoria o de persecución penal es, evidentemente, una función estatal con las excepciones que dicho ordenamiento concede en materia de delitos de acción privada o en el evento de la querella, y ella se adscribe al Ministerio Público.

A su turno, la función de juzgar y penar es igualmente una función estatal que, aunque es provocada por la función acusatoria, ostenta naturaleza diferente de esta, y se encuentra "a cargo de tribunales imparciales del Poder Judicial (entre los que hay que incluir también al jurado popular)" (Cafferata, 2000, p. 91); algún sector de la doctrina estima que la imputación se perfecciona con la acusación, que esencialmente consiste en endilgarle a una persona alguna forma de participación en el acontecer delictivo y en el correlativo pedimento de que sea sometida a juicio por dichos hechos (Cafferata, 2012, p. 175). Por ello, se sostiene que la acusación solo es objeto de verificación judicial cuando expresamente el procesado o su defensor pretenden oponerse a ella, esto es, cuando se puede controvertir su mérito. En ese orden de ideas, la intervención del juez se restringe a la verificación de la plena efectividad de los mismos, por lo que su control no se centra en comprobar las razones de hecho o de derecho por las cuales la fiscalía se abstiene de acusar, sino que gira en torno a la posibilidad de establecer una eventual arbitrariedad y, en caso positivo, declarar la nulidad de la actuación 
de acuerdo con el artículo 168 del Código Procesal Penal de la Nación Argentina.

El juez no es, entonces, en semejante sistema, un simple convidado de piedra, pero tampoco le está permitido sustituir las funciones de otro órgano e imponer una acusación respecto de la que luego emitirá su criterio jurídico. Por supuesto, el aspecto importante encontrado en el proceso penal argentino es la posibilidad de que el juez decrete la nulidad de la actuación cuando la defensa y el imputado se oponen a la acusación -que incluye la imputación-, y, en el ejercicio del derecho de contradicción, el juez estima que se presentaron violaciones a las garantías del imputado, de donde se extrae la posibilidad de que él ejerza control sobre la calificación jurídica que haga el ente acusador, pero, eso sí, solo a petición de parte.

La República de Costa Rica tampoco fue ajena a la implantación de un sistema procesal penal con tendencia oral y acusatoria. En efecto, el Código Procesal fue publicado el 4 de junio de 1996 y las características esenciales del sistema se describen a continuación: juicio oral público y contradictorio como etapa fundamental del proceso penal; separación definitiva de las funciones investigativa y jurisdiccional; Ministerio Público dotado de los medios de investigación necesarios e idóneos para la consecución de una eficiente persecución penal; intervención del juez de garantía en la fase de investigación; garantía de defensa técnica a toda persona a partir del momento en que existen indicios de su vinculación a una investigación de carácter penal; implementación de los mecanismos alternativos de solución de conflictos; y, para culminar, control respecto a la duración de la actuación penal. Por esa razón, la doctrina procesal penal especializada afirma que, en el ámbito de un sistema acusatorio material,

[e]l principio acusatorio significa que el órgano (estatal) habilitado para tomar la decisión de controversias de carácter penal no puede intervenir en el caso a menos que exista un pedido concreto de un particular, cuya actuación se desempeña fuera de la de cualquier órgano público o dependiente del Estado. Tanto en un sistema de acción privada, como en un sistema de acción popular, el órgano llamado a cumplir funciones decisorias necesita de la intervención de un particular que cumpla las funciones de acusador, solicite su pronunciamiento y, a la vez, defina el objeto de discusión (Bovino, 1997, p. 6).

A pesar de lo anterior, el Código Procesal Penal en examen consagra la figura de la nueva calificación jurídica y al respecto establece 
que "si en el curso de la audiencia el tribunal observa la posibilidad de una calificación jurídica que no ha sido considerada por ninguna de las partes, podrá advertir al imputado sobre esa posibilidad, para que prepare su defensa" (artículo 346 de la Ley 7.594), por lo cual se vislumbra normativamente que el juez no es totalmente ajeno a la adecuación típica de los hechos por parte del titular de la acción penal. De manera armónica, el canon 347 de esa misma codificación prevé el concepto de la ampliación de la acusación y le otorga al fiscal, durante el juicio, la facultad de incluir un hecho nuevo o una nueva circunstancia que no haya sido mencionada en la acusación que modifica la calificación legal, debiendo, en todo caso, advertir la variación de la calificación jurídica contenida en la acusación.

Es claro, entonces, que el proceso penal en Costa Rica permite al juez variar la calificación realizada por el órgano acusador, a pesar de tratarse de un sistema penal de corte acusatorio. Al parecer, la facultad para advertir al acusado sobre la posible adecuación jurídica diferente, no contemplada por las partes, tiene un carácter corrector y es propia del juez del proceso, quien es el garante de la legalidad que, en todo caso, debe ser más estricta si se trata de un caso penal.

Pasando a Perú, debe decirse que este país tampoco es ajeno al llamado principio acusatorio, pues, a través delCódigo ProcesalPenal de 2004, se implantó un sistema procesal penal acusatorio-garantista con rasgos adversariales. De este modo, el Ministerio Público es el titular de la acción procesal penal y, en tal sentido, le está atribuido el rol de acusador. Lo anterior, de conformidad con la regla 159 de la Constitución. Del contenido de dicha normativa se vislumbra, pues, la evidente separación de las funciones de investigar y acusar, de la de administrar justicia a través de la creación de un ente autónomo e independiente, no otro que el Ministerio Público, a quien le compete decidir -con la mayor objetividad posible- la viabilidad de sostener una acusación. La constitucionalidad del principio acusatorio ha sido reconocida en diversos pronunciamientos del Tribunal Constitucional de Perú, en los cuales se han destacado como características del sistema acusatorio las siguientes: a) que no puede existir juicio sin acusación, debiendo ésta ser formulada por persona ajena al órgano jurisdiccional sentenciador, de manera que si ni el fiscal ni ninguna de las otras partes posibles formulan acusación contra el imputado, el proceso debe ser sobreseído necesariamente; b) que no puede condenarse por hechos distintos de los acusados ni 
a persona distinta de la acusada; y, c) que no pueden atribuirse al juzgador poderes de dirección material del proceso que cuestionen su imparcialidad (Sentencia 2005-2006-PHC/TC).

Consecuente con la implantación de un nuevo sistema procesal penal, la Sala Penal Permanente de la Corte Suprema de la República del Perú emitió la Queja No 1678, de abril 13 de 2007, en la cual se precisó que el principio acusatorio constituye una de las garantías esenciales del proceso penal que delimita aspectos como la distribución de roles y los supuestos bajo los cuales se desarrollarán las actuaciones penales. Por eso, en dicha sentencia se precisó, además, que la función de acusación es privativa del Ministerio Público, motivo por el cual le está prohibido al órgano judicial ordenar al fiscal que acuse -nemo iudex sine acusatore-. No obstante, se aclara en el mencionado pronunciamiento un aspecto que es relevante para la tesis sostenida en el presente artículo y que alude a la viabilidad de que, acudiendo a una "ponderación de otros derechos fundamentales", se obtenga la nulidad del procedimiento en aquéllas hipótesis en que la decisión del Ministerio Público "incurra en notorias incoherencias, contradicciones o defectos de contenido que amerita nuevo pronunciamiento fiscal y en su caso la ampliación de la propia instrucción" (Espinoza, 2009).

De la anterior revisión del contexto del principio acusatorio y la imputación en diversos países que han implantado regímenes procesales de corte acusatorio puede concluirse que se observan ciertos rasgos similares en los sistemas estudiados, como la división funcional y la existencia de una etapa previa al juzgamiento. Asimismo, en todos los casos se pretende la protección de las garantías fundamentales implicadas en la actuación, especialmente los derechos de defensa y de contradicción. Podemos también señalar que en los países europeos existe un filtro en el proceso penal, en cuya virtud el juez interviene para garantizar que no se inicien juicios sin suficiente fundamento, pudiendo realizar un análisis de la imputación y, en algunos casos, tiene la posibilidad de variar la calificación jurídica.

Es más, en Latinoamérica (y conste que la tendencia se conserva en el reciente Código Nacional de Procedimientos Penales de México de 2014, vigente al 28 julio de 2015) se encontró que algunos países han planteado la necesidad de que el juez intervenga en el proceso para proteger las garantías fundamentales, entre ellas, el principio de legalidad, pudiendo, desde sus competencias, declarar nulidades 
o variar la calificación jurídica e incluso adicionarla. En todos los sistemas penales analizados encontramos la aplicación del principio acusatorio, pero cada legislación ha procurado un mecanismo que le permite al juez controlar la actuación del fiscal, entre ellas, la calificación jurídica de los hechos. De acuerdo con esto, queda claro con el estudio del derecho comparado que un sistema penal de corte acusatorio no se contradice con el control que pueden ejercer los jueces sobre la calificación jurídica de los hechos que haga la fiscalía.

\section{Alcance y finalidad del principio acusatorio en Colombia}

Con la entrada en vigencia de la Ley 906 de 2004 en Colombia se implantó un sistema acusatorio de naturaleza adversarial -de partes- (Corte Constitucional. Sentencia C-144 de 2010), regido bajo los principios de oralidad, concentración, contradicción, igualdad, publicidad, inmediación, entre otros, en el cual actúa como director del proceso un tercero imparcial denominado juez (Corte Constitucional, Sentencia C-260 de 2011), a quien, por mandato legal, le está prohibido ejercer algún tipo de control en torno a la denominación típica, dada por la fiscalía a las diversas conductas que por acción u omisión, lesionan los bienes jurídicos tutelados por el derecho penal.

La figura del juez de control de garantías, introducida al nuevo sistema, obedece al diseño de una institución que controle el ejercicio de los poderes estatales en la búsqueda de la verdad, el acopio del material probatorio y la verificación de sospechas, "en el escenario de un sistema político-constitucional que consagra derechos y garantías para el ciudadano intervenido punitivamente" (Zuluaga, 2007, p. 134). Esta comprensión del rol del juez de garantías permite sostener la idea de un derecho procesal penal "dimensionado en clave de derecho constitucional aplicado" (Arango, 2010, p. 232), si se toma en cuenta, además, el desequilibrio existente entre las partes, que se evidencia con mayor intensidad en las fases iniciales del proceso penal.

En el proceso penal acusatorio se ha justificado la prohibición del control judicial sobre la imputación jurídica hecha por el fiscal, al considerar que el ejercicio de la acción penal es potestad de la Fiscalía General de la Nación y/o de sus delegados (artículos 250 de la Constitución Política y 66 de la Ley 906 de 2004) y, en tal medida, es el ente acusador quien decide, de manera autónoma, si en un determinado caso ejerce o no la acción penal; igualmente, 
si renuncia a la misma en aplicación del principio de oportunidad, regulado en el artículo 321 y siguientes del Código de Procedimiento Penal. Se requiere, así, de una acusación que active la intervención jurisdiccional, para que los jueces conozcan la pretensión punitiva de la Fiscalía en representación del Estado y adopten la decisión. Además, al acusado le asisten los mismos derechos que al acusador; por ello, se establece un debate oral, público, concentrado y contradictorio. Estas notas dominantes permiten la caracterización de un proceso penal como acusatorio (Carbonell, 2008, p. 67).

Para otros doctrinantes, el principio acusatorio se define como una de las piedras angulares del denominado sistema penal acusatorio, el cual es considerado además como el verdadero proceso penal (Gómez, 2003, p. 74), cuyos aspectos esenciales han sido clarificados así: la titularidad en el ejercicio de la acción penal radicada en la Fiscalía General de la Nación de acuerdo con lo establecido en el Acto Legislativo 03 de 2002; la división de las funciones de acusación y juzgamiento, garantizándose total independencia e imparcialidad en las distintas etapas del proceso penal y, finalmente, la autoridad judicial a quien se le atribuya el juzgamiento debe estar al margen de cualquier conocimiento previo a su actuación (Montero, 1994, p. 537). Posición similar esgrimen Sandoval y Del Villar (2013, p. 78) cuando insisten en que "[u]na de las características de este sistema es la separación que existe entre las funciones de acusación, defensa y juzgamiento".

En ese orden, las principales manifestaciones de dicho postulado son las siguientes: ninguna persona puede ser condenada si no se ha formulado contra ella, evidentemente por un órgano distinto a quien tenga la función de juzgar, una acusación de la cual haya tenido la oportunidad de defenderse con todas las garantías; la imputación debe tener lugar en la etapa de instrucción; exige que el imputado no declare como testigo desde el momento en que resulte sospechoso de haber participado en la ejecución del delito; y congruencia fáctica -identidad del hecho punible-y jurídica. Ésta última, en aras de que no se produzca indefensión (Jaén, 2008, p. 198).

Para recapitular, los contenidos del principio acusatorio en Colombia se reducen a las siguientes premisas: no puede existir condena sin acusación (acusación previa y sentencia posterior), las funciones de acusar y proferir sentencia no solo deben encontrarse claramente separadas sino, además, ubicadas en espacios diferentes, motivo por el cual a quien acusa le está vedado juzgar; el juez no 
puede desbordar los límites de la acusación: principio de congruencia entre acusación y sentencia; la Fiscalía no debe estar legitimada para afectar derechos fundamentales ni adoptar decisiones con efectos de cosa juzgada, pues las mismas deben provenir de un tercero imparcial; y, se deben propiciar espacios para el reconocimiento de los derechos de la víctima: verdad, justicia y reparación (Urbano, 2013, p. 38).

La apreciación del principio acusatorio como pilar fundamental del denominado sistema acusatorio se encuentra también en los planteamientos de Bernal y Montealegre (2013, p. 197), quienes han sido enfáticos en atribuirle ciertas consecuencias, así: a) las funciones de instrucción y juzgamiento están atribuidas a dos órganos distintos e independientes; b) la decisión de responsabilidad penal debe definirse a petición de un órgano acusador; c) debe existir identidad entre la acusación y la sentencia; d) tiene aplicación legal el axioma denominado reformatio in pejus; e) la fase de investigación se concreta en una actividad preparatoria del juicio oral que aporta los presupuestos indispensables para que se materialice la garantía de contradicción; f) el proceso penal se traduce en una actividad propia del Estado y está regido por el principio de legalidad tanto de la actuación como de la prueba; $y$, g) la oralidad y la publicidad como aspectos formales que deben imperar en los procedimientos.

La esencia del principio acusatorio, en los términos en que se ha entendido en Colombia, se expresa entonces en su funcionamiento con la existencia de dos partes adversarias -Fiscalía y acusado (defensa)-y un tercero imparcial denominado juez, quien, fungiendo como un árbitro, decide a cuál de ellas le concede la razón, partiendo de las pruebas legalmente allegadas, incluidas y practicadas en la audiencia de juicio oral, y sometidas a la contradicción de la parte contraria -artículo 16 de la Ley 906 de 2004- (Corte Suprema de Justicia, Sentencia de noviembre 27 de 2013). Por lo tanto, la denominación del proceso como 'acusatorio', tiene un fundamento propio y, por ende, no puede catalogarse como un simple apelativo que le otorga mayor valor al sistema, sino que debe ser visto como algo esencial dentro del Estado social de derecho (Corte Suprema de Justicia, sentencia de noviembre 27 de 2013), al hilo del cual se ofrecen unas garantías especiales derivadas de dicho modelo de procedimiento penal, que se entendió en su momento como más acorde con la forma de Estado concebido en la Constitución de 1991. 
La jurisprudencia ha sido consistente en señalar que el sistema procesal penal acogido de manera progresiva en Colombia, a partir del $1^{\circ}$ de enero de 2005 tiene sustento en el denominado principio acusatorio

[e]ntendiendo por tal, básicamente que no hay proceso sin acusación (nemo iudex sine acusatore), apareciendo como su nota más distintiva el hecho de que acusación no puede ser formulada por el mismo juzgador, esto es, existe separación absoluta entre las funciones de acusación y juzgamiento (Corte Suprema de Justicia, Sentencia de octubre 16 de 2013).

En otros términos, en el sistema penal implantado a través de la Ley 906 de 2004, la demostración del delito -materialidad de la conducta y responsabilidad del autor- es una labor propia de la Fiscalía, la cual se enfrenta en igualdad de condiciones con la defensa, contienda que es dirimida por un tercero imparcial denominado juez. En este modelo de proceso penal claramente se diferencian entonces tres roles fundamentales: acusación, defensa y juzgamiento (Guerrero, 2005, p. 184). A este respecto, recuérdese que la Corte Constitucional señaló cómo el Acto Legislativo 03 de 2002 introdujo en Colombia la vigencia del principio acusatorio y, sobre el particular, precisó que hace alusión a la máxima nemo iudex sine actore, que significa la clara separación funcional entre el órgano que acusa y el que juzga (Sentencia C-591 de 2005).

Como es obvio, la consecuencia elemental del denominado principio acusatorio es que el juez es ajeno al conflicto entre las partes -Fiscalía y defensa-y, en tal medida, debe actuar con absoluta imparcialidad y plena garantía del derecho a la igualdad que es uno de los principios fundantes del Estado social de derecho. En cuanto a la imparcialidad, ha dicho el Tribunal Europeo de Derechos Humanos que la misma debe entenderse en los siguientes términos:

[a]usencia de prejuicios o parcialidades en el juzgador que debe ser considerada tanto subjetiva como objetivamente. En el aspecto objetivo, todo juez en relación al cual pueda haber razones legítimas para dudar de su imparcialidad debe ser apartado, ya que lo que está en juego, según se manifestó, es la confianza que los tribunales deben inspirar a los ciudadanos en una sociedad democrática (Piersack vs. Bélgica, 1982).

Aunado a ello se tiene que, de conformidad con lo previsto en el Código de Procedimiento Penal colombiano, los jueces, en ejercicio 
de las funciones de control de garantías, preclusión y juzgamiento deben orientarse por el imperativo de "establecer con objetividad la verdad y la justicia" (art. $5^{\circ} \mathrm{CPP}$ ). Esa objetividad significa que el juez es un tercero imparcial frente a la controversia que se suscita entre las partes, sin que de ninguna manera implique que le esté vedado actuar como garante de los derechos fundamentales, pues, en todo caso, está sometido al imperio de la ley como lo establece el canon 230 del Estatuto Superior.

Otro elemento esencial para que el principio acusatorio opere es el de la independencia que el funcionario judicial debe tener frente a los órganos legislativo y ejecutivo. El primero, en cuanto el Congreso no puede interferir en las decisiones judiciales ni someter al juez a presiones indebidas. Igualmente, el ejecutivo tampoco puede someter a un juez a presiones ni condicionamientos en el ejercicio de la actividad de administrar justicia. No es ocioso indicar, además, la incidencia de la garantía del derecho a conocer los cargos que pesan en su contra y de la situación fáctica que motiva la iniciación del proceso con que cuenta el sujeto pasivo de la acción penal, y el acto procesal de la formulación de la imputación. Estas aserciones tienen como consecuencia palmaria la imposibilidad de imponer una condena si, de manera previa, no se han formulado la imputación y la acusación, y si sobre estos extremos no se ha tenido la oportunidad de defensa y de contradicción. Por ello, es indispensable conocer los hechos materia de imputación y de acusación, sobre todo si se tienen en cuenta que "[q]uien no conoce los hechos que se le imputan se encuentra en un estado de indefensión, no puede realizar una defensa contradictoria, ni estaría en plano de igualdad de armas procesales"' (Toro, 2012, p. 191).

Este conocimiento por parte de la persona procesada se extiende a las circunstancias de tiempo, modo y lugar, la denominación jurídica del hecho, el grado de participación, la sanción contemplada por el legislador y los elementos de convicción (con las restricciones propias en este sentido para la etapa de la imputación), y, en suma, no puede limitarse a una narración irrelevante jurídicamente, sino que debe comprender criterios normativos y su adecuación jurídica, "ya que sin lugar a dudas el acto de imputación tiene que estar irradiado por las garantías que establece el debido proceso" (Arango, 2010, p. 234). Para concluir este aparte, debe decirse con el profesor Ferrajoli, quien resume la esencia del principio acusatorio, que se denomina tal 
[a] todo sistema procesal que concibe al juez como un sujeto pasivo rígidamente separado de las partes y al juicio como una contienda entre iguales iniciada por la acusación, a la que compete la carga de la prueba, enfrentada a la defensa en un juicio contradictorio, oral y público, y resuelta por el juez según su libre convicción (Ferrajoli, 2001, p. 564).

Para el connotado autor, pues, el seguimiento de estos principios garantiza el mayor grado de racionalidad y de fiabilidad del juicio, que redunden en la tutela de la persona contra la arbitrariedad (Ferrajoli, 2001, p. 34). Es evidente, entonces, que la facultad de imputar, y posteriormente de acusar, es un poder absoluto radicado en la Fiscalía, el cual no se encuentra sometido a límites o controles, motivo por el cual se corre el riesgo de que cualquier persona sea imputada o acusada sin un soporte razonable y, en el peor de los casos, sin fundamento alguno (Urbano, 2013, p. 19).

\section{Variación de la imputación jurídica a solicitud del juez de garantías cuando se desconoce el principio de taxatividad}

Desde el acápite introductorio se ha venido sosteniendo que el juez, en el proceso penal colombiano, debe tener expresas facultades para realizar un control respecto de la denominación jurídica que a los hechos le atribuye la Fiscalía cuando formula imputación, tesis que encuentra plena justificación y respaldo en cinco aspectos esenciales que se enunciarán ahora, pero que serán objeto de análisis con posteridad y a la luz de los pronunciamientos de las altas cortes, las cuales también se han ocupado recientemente del tema: el principio de taxatividad como integrante del postulado de legalidad y pilar fundamental del debido proceso previsto en el artículo 29 constitucional. Asimismo, el canon 230 ibídem que dispone que los jueces en sus actuaciones y decisiones están sometidos al imperio de la ley y el artículo 228 del mismo estatuto en torno a la prevalencia del derecho sustancial. Además, el principio acusatorio frente a los acuerdos y negociaciones, respecto de los cuales sí existe un control judicial por parte del juez de conocimiento (Bernal y Montealegre, 2013, pp. 898-899). También, la real y eficaz garantía de los derechos de las víctimas a la verdad y a la justicia, pues su intervención en el proceso penal no se limita al beneficio económico que pretenden obtener con la indemnización de los perjuicios, máxime cuando la Fiscalía debe orientarse por el principio de objetividad, con miras a establecer la verdad de los hechos (Bernal y Montealegre, 2013, p. 69 y ss.). Y, de igual forma, la facultad del juez de conocimiento de 
realizar control a la acusación cuando existe vulneración grave al principio de taxatividad; y el principio de congruencia, el cual, en Colombia, se predica no sólo respecto de la acusación y la sentencia, sino además entre la imputación y la acusación.

\section{El principio de taxatividad y la prevalencia del derecho sustancial}

Debe recordarse que, inmerso en el derecho fundamental al debido proceso -artículo 29 del Estatuto Superior-, se encuentra el principio de determinación o taxatividad y es deber de los funcionarios judiciales, tal y como lo enseña la jurisprudencia, ejercer un control sobre el mismo (Corte Suprema de Justicia, Sentencia de diciembre 5 de 2007). Ese mismo canon constitucional consagra el denominado principio de legalidad o nullum crimen, nulla poena sine lege, postulado ampliamente reconocido y aceptado como inherente al Estado social de derecho, sobre el cual se sustenta la taxatividad que se predica del derecho penal, característica con la cual se garantiza, entre otros aspectos, la seguridad, para quienes infringen la ley, de que la pena será impuesta por el juez competente y que este deberá aplicar la definida previamente en la ley (Corte Constitucional, Sentencia C-739 de 2000).

El principio de legalidad representa, entonces, para el imputado dentro del proceso acusatorio, la garantía o seguridad de que tanto el delito como la sanción penal deben estar determinados en una ley previa, sin que ello genere confusiones o interpretaciones ambiguas. Dicho postulado ha sido el resultado de una evolución dogmática que se fundamenta sobre tres bases teóricas: garantizar la realización de la justicia en condiciones de plena igualdad; obtener la más completa satisfacción posible de la pretensión penal material; y el monopolio de la acusación en poder de órganos de persecución penal (Sintura, 2005, p. 29).

Por ello, a la Fiscalía General de la Nación le corresponde la titularidad de la acción penal y, acorde con el principio de legalidad, deberá actuar ante la existencia de hechos que revistan las características de un delito, realizando, por lo demás, una correcta adecuación típica de los mismos en garantía de dicho postulado, sin dejar de lado que el acto de la imputación ya supone, de alguna manera, el cuestionamiento de la presunción de inocencia (Arango, 2010, p. 238). Entonces, si el fiscal no respeta esa garantía constitucional y judicial, surge la necesidad de que exista un control 
por parte del juez de control de garantías, quien debe propender por su materialización real y efectiva. Incluso, es la propia Constitución la que le impone al funcionario judicial asegurar el respeto de los valores, principios y derechos constitucionales de manera razonable (Bernal y Montealegre, 2013, p. 60).

Cabe, entonces, añadir en defensa de la necesidad de control material por parte del juez de control de garantías que, si la intención del legislador hubiese sido la de regular la formulación de la imputación como un mero acto de comunicación formal, no habría dispuesto que es necesario llevarlo a cabo en audiencia frente a un juez, sino que bastaría al efecto que la diligencia se hiciese con prescindencia del juzgador y solamente ante la Fiscalía. Igualmente, si se trata de una sencilla comunicación formal, sin posibilidad alguna de control material, podría afirmarse que existen esferas del proceso penal donde no es necesaria la vigilancia sobre el respeto de las garantías de los intervinientes, postura que desde ningún ángulo se sostiene.

Es de resaltar que, en el ámbito doctrinario, algunos autores han avalado, incluso, la figura del rechazo de la imputación frente a determinadas hipótesis y uno de los argumentos que respaldan esa postura es que el juez tiene el deber ineludible de velar por la legalidad del proceso y la garantía de los derechos de quienes intervienen en la actuación penal (Bernal y Montealegre, 2013, pp. 152-153); ello, sin lugar a dudas, significa que su rol al interior del proceso y, concretamente, en la imputación, no puede ser el de un simple espectador. Otros autores insisten sobre este entendimiento puesto que si se concibe la figura del juez de control de garantías como la de un convidado de piedra en la diligencia, se entendería que no cumple con ningún cometido en procura de la efectividad de los derechos sustanciales, y tal no es el espíritu del instituto del juez de control. Así las cosas, en eventos como el de la discordancia entre la narración de los hechos presentada por el fiscal y la calificación jurídica asignada a los mismos, "el juez está obligado a rechazar la imputación y sobre esta decisión no cabría ningún recurso" (Rojas, 2010, p. 205).

Por tal razón, la jurisprudencia (Corte Suprema de Justicia, Sentencia de octubre 16 de 2013) ha precisado en múltiples pronunciamientos que el juez de conocimiento tiene la potestad de declarar la nulidad de formulaciones de imputación, dentro de su independencia y autonomía judiciales, pues no se halla forzado a admitir la denominación jurídica que a los hechos le atribuye la Fiscalía. A renglón seguido, cuestiona tal apreciación, habida cuenta de que la misma 
desnaturaliza la esencia del sistema acusatorio adversarial y desdibuja la separación de funciones -acusación y juzgamiento- que caracteriza el denominado principio acusatorio, en tanto se le permite al juez prácticamente imponer su particular teoría del caso frente a los hechos, cuando la definición de la misma es potestad exclusiva del ente fiscal. Desde luego, añádase, esa crítica no resulta suficiente para dejar de lado el principio de legalidad en tanto integrante del derecho fundamental al debido proceso, como tampoco la garantía de respeto de los derechos de las víctimas a la verdad y la justicia, cuando la denominación jurídica que a los hechos le atribuye el titular de la acción penal difiere notablemente del acontecer fáctico.

\section{El control judicial respecto de los acuerdos y negociaciones}

Tratándose de los llamados preacuerdos, no existe mandato legal que ordene su aprobación integral, pues el inciso $4^{\circ}$ del canon 351 de la Ley 906 de 2004 es claro al establecer que aquellos obligan al juez de conocimiento, siempre y cuando no vulneren o quebranten garantías fundamentales, cuya titularidad no es exclusiva del acusado, sino también de las víctimas; ahí es, precisamente, donde surge incuestionable el respeto por el principio de taxatividad. Por ello, resulta atinado indicar que la Corte Suprema de Justicia señala que si el juez, al examinar un preacuerdo o negociación encuentra que en su integridad o en alguno de sus aspectos se vulneran las garantías fundamentales, debe declararlo así y, al mismo tiempo, establecer qué parte del preacuerdo se ajusta a la Constitución y a la ley, porque no tiene sentido invalidar aquello que se ajusta al derecho (Corte Suprema de Justicia, Sentencia de septiembre 12 de 2007).

En ese orden de ideas, es viable desaprobar los preacuerdos cuando los mismos desconocen garantías constitucionales o no se ajustan al principio de legalidad, frente a lo cual el juez no puede asumir una actitud pasiva, ser un simple espectador o un convidado de piedra. Una errónea adecuación típica de la conducta, sin lugar a dudas, se traduce en una vulneración del principio de legalidad y debe permitirse la intervención del juez dentro del deber que le asiste de ejercer un control constitucional y legal respecto de la actuación penal, toda vez que esta intervención se encuentra encaminada a proteger los intereses constitucionales que se imbrican en la actuación, no simplemente un acto de comunicación formal, y tal proceder de carácter global conduce a una "legitimación interna dentro de la misma audiencia”" (Rojas, 2010, p. 204). 
En el caso analizado por la Corte en la decisión citada, el tribunal de segunda instancia declaróla nulidad parcial del acuerdo celebrado entre las partes, pues, en su criterio, la imputación por el delito de lesiones personales no era congruente con los hechos sucedidos, a lo que denominó supuesto fáctico real, en la medida en que de los elementos probatorios era acertado inferir la comisión de un delito de tentativa de homicidio y, por ende, la imputación, en los términos así indicados, no podía constituir fundamento válido de un fallo condenatorio. En sentir de esa alta Corporación, le asistió razón a la segunda instancia cuando invalidó el acuerdo celebrado entre las partes, pues "no se hace justicia material cuando el fallo no tiene un referente fáctico correcto" (Corte Suprema de Justicia, sentencia de septiembre 12 de 2007), apreciación que indudablemente respalda la tesis planteada en este trabajo, en el sentido de que en la adecuación típica de la conducta debe respetarse el principio de determinación, pues en la hipótesis contraria no se le permitiría a las víctimas la garantía de los derechos a la verdad y la justicia.

Acertó , pues, el tribunal cuando anuló la imputación por el delito de lesiones personales, dado que de los elementos materiales probatorios podía inferirse que los acusados le propinaron múltiples disparos a la víctima y uno de ellos le impactó el tórax, por lo que para la Corte resultó disparatado que se aludiera a unas lesiones personales sin desconocer-además- que el monto de la pena en ese caso concreto iría en contravía del principio de proporcionalidad que rige las sanciones penales, si se tiene en cuenta la gravedad del comportamiento. De este modo, concluyó la Corte, que "el homicidio agravado en grado de tentativa era un asunto tan evidente que no se podía desconocer" (Corte Suprema de Justicia, sentencia septiembre 12 de 2007).

En fin, a este respecto recuérdese que, en materia de preacuerdos, al ser analizado el numeral $2^{\circ}$ del artículo 350 de la Ley 906 de 2004, en lo atinente a los términos de la imputación, se declaró exequible de manera condicionada la aludida normativa en aras de salvaguardar, precisamente, la legalidad de los preacuerdos celebrados entre las partes en el proceso penal. El fundamento central de dicho pronunciamiento consistió en que a la Fiscalía le está permitido tipificar el comportamiento de manera específica, con miras a disminuir la pena y, asimismo, excluir alguna causal de agravación punitiva o un cargo específico en el entendido de que "no puede darles a los hechos sino la calificación jurídica que verdaderamente corresponda" (Corte Constitucional, Sentencia C-591 de 2005). 
Obsérvese cómo el propio órgano de cierre en materia constitucional, fijó el criterio de que, tratándose de negociaciones con el imputado o acusado, las mismas deben estar regidas por los postulados de legalidad, taxatividad, transparencia y lealtad con la administración de justicia, al momento de atribuirle a los hechos una denominación jurídica concreta. Lo anterior significa, entonces, que en la labor del fiscal de realizar la adecuación típica de los hechos, cuando de preacuerdos se trata, la discrecionalidad de dicho ente no puede ser absoluta, pues de ninguna manera está facultado para excluir elementos relevantes en aras de llevar a feliz término una negociación. También, téngase en cuenta al respecto que, si bien el fiscal es el titular de la acción penal, no cuenta con absoluta libertad para escoger en forma deliberada el tipo penal al cual se adecuan los hechos materia de investigación, pues, en todo caso, ese proceso de adecuación típica debe guardar armonía y correspondencia con las circunstancias de tiempo, modo y lugar en que tuvieron ocurrencia los hechos. Sobre ese particular, la Corte Constitucional, en el fallo citado, precisó: "[e]l Fiscal no tiene plena libertad para hacer la adecuación típica de la conducta [léase imputar], pues se encuentra limitado por las circunstancias fácticas y jurídicas que resultan del caso".

Tal criterio fue reiterado por la Corte Constitucional cuando, al referirse a la figura de los acuerdos y preacuerdos, señaló que la existencia de tales mecanismos de terminación anticipada del proceso penal, por sí mismos, no desconocen el debido proceso como garantía fundamental, máxime cuando el fiscal no es absolutamente discrecional al momento de tipificar la conducta punible en tanto que, "en la valoración del acuerdo, el juez velará porque el mismo no desconozca o quebrante garantías fundamentales del imputado y de la víctima" (Sentencia C-059 de 2010). De esta forma, a pesar de que la Fiscalía tiene, de conformidad con la Constitución, la competencia exclusiva para iniciar la acción penal, lo cierto es que la Corte Constitucional y la Sala de Casación Penal de la Corte Suprema de Justicia han aclarado que la calificación jurídica de los hechos no es una potestad discrecional de la misma, y, por ello, se encuentra sometida a control judicial y a debate por parte de la defensa cuando dicha calificación afecte el principio de determinación o taxatividad.

\section{La garantía de los derechos de las víctimas a la verdad y a la justicia}

No puede desconocerse que el proceso de adecuación típica también tiene incidencia en los derechos de las víctimas a la verdad y a 
la justicia, de ahí que la denominación jurídica que la Fiscalía atribuya a los hechos debe estar regida por el postulado de taxatividad. La Sala de Casación Penal de la Corte Suprema de Justicia, al referirse al tema de las negociaciones, fue clara al sostener que las mismas deben llevarse a cabo

[d]entro de márgenes de razonabilidad jurídica, es decir, sin llegar a los extremos de convertir el proceso penal en un festín de regalías que desnaturalizan y desacreditan la función de administrar justicia, en un escenario de impunidad, de atropello a la verdad y al derecho de las víctimas de conocer la verdad (Corte Suprema de Justicia, Sentencia de 12 de septiembre de 2007).

Ese margen de discrecionalidad que tiene la Fiscalía no puede, de manera alguna, ser absoluto. Cada que dicho ente califica jurídicamente los hechos sometidos a su investigación, lleva a cabo un juicio de valor que el legislador ha excluido de control judicial con fundamento, precisamente, en la titularidad que, de la acción penal, ostenta de manera exclusiva. Sin embargo, los límites del fiscal en cumplimiento de dicha labor han sido, aunque de manera tímida, sentados por cierta parte de la jurisprudencia nacional y se centran principalmente en el respeto de los derechos de las víctimas a obtener justicia y a conocer la verdad de los hechos, propósito que puede catalogarse como razonable a la luz de nuestro Estado social de derecho.

Dicha postura encuentra reparos en cierto sector del derecho comparado; es así como, en la legislación procesal chilena, el juez solamente constata la razonabilidad jurídica de la calificación de la conducta. Se ha expresado al respecto lo siguiente:

[e]n estos supuestos, entonces, el juez de garantía únicamente verificaría la razonabilidad jurídica de la calificación de los hechos efectuada por el fiscal, controlando su plausibilidad dogmática, pero no ejecutaría un control de legalidad fuerte que conlleve un pronunciamiento autónomo o la expresión de una opinión jurídica propia sobre el fondo de la calificación jurídica de los hechos materia de la investigación. De lo contrario, se corre el riesgo de suponer al Ministerio Público incluido en el poder judicial y bajo la supervisión directa de los jueces al ejecutar su labor requirente, imponiéndole los criterios jurisprudenciales utilizados por la judicatura, por vía directa o indirecta (Rodríguez, 2013, p. 675-676).

No puede desconocerse, además, que la Fiscalía General de la Nación debe enmarcar sus actuaciones dentro del denominado 
principio de objetividad de acuerdo con los dictados del artículo 115 de la Ley 906 de 2004, pues la finalidad del proceso penal no se circunscribe a la demostración de la materialidad de la conducta y de la responsabilidad de su autor, sino que se hace extensiva -tal como lo ha reconocido en múltiples oportunidades nuestro máximo tribunal en materia constitucional- a la efectiva garantía de los derechos de las víctimas, a la denominada triada de verdad, justicia y reparación (Corte Constitucional, Sentencia C-228 de 2002).

Desde luego, este es otro de los fundamentos por los cuales se considera de suma importancia que el juez de control de garantías ejerza un control sobre la adecuación típica que de la conducta realiza la Fiscalía al momento de la formulación de imputación, pues a las víctimas les asiste el derecho a que exista una congruencia entre los hechos realmente sucedidos y su denominación típica, en aras de la mayor coincidencia entre la denominada verdad procesal y la verdad real. Es así como el juez de control de garantías debe requerir al fiscal en la audiencia de formulación de imputación, para que aquél realice una adecuación correcta de los hechos jurídicamente relevantes, no sólo en garantía del principio de determinación, sino en procura de hacer efectivos los derechos de las víctimas a la verdad y la justicia.

Los detractores de esta posición (Bernal y Montealegre, 2013, p. 779) aducen que tal situación no permite mantener incólume el denominado principio acusatorio, como que tampoco garantiza el postulado de imparcialidad, en la medida en que el juez podría interferir en el ejercicio de la acción penal, cuya titularidad es exclusiva de la Fiscalía en representación del Estado. Sin embargo, no puede obviarse que el sistema de enjuiciamiento que se introdujo en Colombia a través del Acto Legislativo 03 de 2002 no es puramente acusatorio, sino mixto, en la medida en que está influenciado por los sistemas anglosajón y continental europeo (Guerrero, 2006, p. 1056).

Por ejemplo, en aquellos países que están regidos por un sistema acusatorio puro, los denominados jurados de conciencia también están reglamentados (López, 2012, p. 1397 y ss.), lo que no acontece en Colombia, pues, a pesar de que en el aludido Acto Legislativo se hizo mención a la posibilidad de que los particulares pudiesen actuar como jurados en las causas criminales, en la Ley 906 de 2004 nada se dijo al respecto, lo cual ratifica que efectivamente en nuestro país el sistema procesal no es puramente acusatorio y, en tal medida, 
no se halla dificultad alguna para que el juez de control de garantías en la audiencia de formulación de imputación, tenga la potestad de requerir a la Fiscalía para que realice una correcta adecuación típica de la conducta, sin que ello implique, como se ha sostenido por muchos, que se desdibuje o desnaturalice la esencia de nuestro sistema procesal penal.

El juez de control de garantías no puede cumplir, entonces, una función de simple espectador, por el contrario, debe desempeñar un rol activo en la defensa de los derechos fundamentales de los intervinientes en todo momento procesal en que sea pertinente su participación, aun cuando no es ésta la única postura existente, toda vez que

[s]i bien la Ley 906 dispuso que su función tendría que desarrollarse bajo la perspectiva de un auténtico juez constitucional, dinámico, controlador, que ejerce control material a la imputación, otros sostienen que su función es solo formal, en cuanto ante él no se discute la responsabilidad penal (Sandoval y Del Villar, 2013, p. 79).

Al respecto, recuérdese que la Sala de Casación Penal de la Corte Suprema de Justicia, a propósito de la variación de la imputación jurídica por parte de la Sala de conocimiento de Asuntos de Justicia y Paz, ha hecho expresa la facultad para tal modificación, con fundamento en el ejercicio del control material. La aludida Corporación sostuvo sobre el particular, y refiriéndose a la intervención de la Sala de Justicia y Paz, que

[e]stá en la obligación de verificar, ya sea por iniciativa propia o en virtud de la controversia que planteen los intervinientes, en especial las víctimas y el Ministerio Público, no sólo que los estándares mínimos de verdad, dentro del contexto del grupo armado, se han respetado, sino que lo definido típicamente se corresponde con la realidad (Corte Suprema de Justicia, Auto de marzo once de 2010).

Y aunque el organismo citado aludió en dicho pronunciamiento a aquellos asuntos que se tramitan de conformidad con la Ley de Justicia y Paz, dentro de un contexto de interpretación razonable y sistemática, deja entrever la posibilidad de que el juez de control de garantías pueda intervenir con la finalidad de protejer el principio de determinación; en otros términos, que lo definido típicamente por el ente acusador se corresponda con la realidad, en aras de que prevalezca el derecho a la verdad. Y es que, desde una perspectiva más cercana al principio de legalidad, el margen de 
discrecionalidad de la Fiscalía se ve seriamente limitado, toda vez que la denominación jurídica que se atribuye a una determinada conducta es un imperativo del que únicamente puede prescindirse frente a circunstancias previamente reguladas (Barbosa, 2005, p. 90).

Si la Fiscalía, como titular de la acción penal, contara con un margen absoluto de discrecionalidad al momento de encuadrar los comportamientos en los tipos penales descritos por el legislador, se desconocerían todas las garantías inmersas en el artículo 29 de la Constitución Política, en tanto que se soslayarían los postulados de verdad y justicia a que tienen derecho las víctimas en vigencia de la Ley 906 de 2004, los mismos que sin lugar a dudas deben ser reconocidos por el propio ente fiscal. Igualmente, es el juez quien, como máximo director del proceso penal, debe cumplir el mandato constitucional del artículo 230 según el cual los jueces solo están sometidos al imperio de la ley, y, en virtud de ello, siempre serán garantes del cumplimiento de la misma; por ello, en su función de control de garantías tienen el deber de verificar la legalidad de la imputación y ello no implica la intromisión en la función de la Fiscalía de acusar, pues se supone que ella tiene sus argumentos para soportar su calificación jurídica de conformidad con la ley.

\section{Control de la acusación por vulneración grave al principio de taxatividad}

Otro de los argumentos que respaldan la tesis aquí planteada, es el de la facultad otorgada al juez de conocimiento de realizar el control a la acusación cuando existe grave vulneración al principio de taxatividad, potestad que ha sido definida por la Corte Suprema de Justicia en reiterados pronunciamientos y que, sin lugar a dudas, constituyen un referente valioso, en la medida en que esos mismos argumentos son de gran utilidad para establecer la necesidad de que el juez de control de garantías intervenga desde la imputación en aquéllas hipótesis en las cuales la Fiscalía no respeta el principio de legalidad al momento de realizar la adecuación típica de las conductas.

$\mathrm{Al}$ respecto, se debe recordar que la Corte Suprema de Justicia al decidir la tutela interpuesta por una fiscal seccional de la ciudad de Pereira por presunta vulneración del derecho fundamental al debido proceso - por cuanto el tribunal de esa capital improbó un preacuerdo celebrado con el acusado de un delito de acto sexual abusivo con menor de 14 años, por presunto desconocimiento del 
principio de legalidad-, aclaró que no es acertada la idea difundida entre los servidores judiciales en el sentido de que el juez no puede ejercer ningún tipo de control a la Fiscalía en los procesos tramitados bajo el imperio de la Ley 906 de 2004 y, en virtud de ello, consideró necesario efectuar algunas precisiones sobre el particular señalando que, por regla general, es improcedente el control material de la acusación, pero en el caso de actuaciones que, de forma grosera y arbitraria, vulneren las garantías fundamentales de las partes y los intervinientes, el juez podrá efectuar el control que supere lo formal (Corte Suprema de Justicia, Sentencia de octubre 16 de 2013).

Igualmente, sintetizó las razones en las cuales se fundamenta la facultad del juez para hacer el aludido control material; con base en ellas puede afirmarse que aquel debe vislumbrarse incluso desde el mismo momento de la imputación en sede de garantías: en primer lugar, no puede desconocerse que, conforme a los principios que orientan el sistema penal acusatorio introducido con el Acto Legislativo 03 de 2002, las garantías fundamentales de las partes e intervinientes en la actuación procesal, no pueden ser vulneradas, trátese de procesos ordinarios o abreviados, esto es, aquellos que culminan por aceptación unilateral de cargos, preacuerdos o por aplicación del principio de oportunidad.

El propio ordenamiento jurídico le impone al juez el deber de hacer control material para salvaguardarlas, mandato que se ve reflejado en innumerables disposiciones de la Constitución Política, entre otras, en los artículos 1, 4, 13 y 228, los cuales se refieren, en su orden, a la categoría de derecho que se le otorga al Estado colombiano, la superioridad de la Constitución al atribuirle la calidad de norma de normas, la igualdad de trato jurídico en las actuaciones penales y la prevalencia del derecho sustancial en el desarrollo de las mismas (Corte Suprema de Justicia, Sentencia octubre 16 de 2013). Esta posición es sostenida por Arango (2010), quien no duda al indicar que la imputación no puede agotarse en un simple acto de impulsión procesal o acto de comunicación, y sin llegar al extremo de la imposición de criterios por parte del juez, o de la invasión de las funciones del titular de la acción penal "todo parece indicar que es necesario que se ejerza un control material sobre el mismo"' (p. 236).

En segundo lugar, el denominado control constitucional que se le confía al juez involucra asimismo un control material, dado que a 
este funcionario se le encarga, entre otros, la guarda de los principios de establecer con objetividad la verdad y la justicia, el obrar con sujeción a la legalidad, el respeto por los derechos fundamentales de las personas que intervienen, la eficacia de la justicia y la prevalencia del derecho sustancial (Corte Suprema de Justicia, Sentencia de octubre 16 de 2013).

En tercer lugar, si bien la Fiscalía es la titular de la acción penal, los pilares constitucionales enunciados con antelación también le atribuyen al juez el deber de administrar justicia en un caso concreto, pues, si aquella debe comunicar al indiciado unos hechos jurídicamente relevantes a la luz del derecho penal y a partir de ese momento se formaliza la relación jurídico-penal, surgen de este modo derechos y deberes de naturaleza sustancial para las partes -Fiscalía y defensa- e intervinientes, por cuya protección y efectividad debe velar el juez en todo momento procesal y, así, lograr el ideal de justicia material por el que propende nuestro Estado social de derecho. El control sobre la imputación no puede ser, entonces, meramente factual sino también comprensivo de lo jurídico (Sandoval y Villar, 2013, p. 82).

La Corte Suprema de Justicia, en la decisión a la que se ha hecho referencia en torno a la intervención excepcional del juez de control de garantías en la imputación, puntualizó que debe respetarse la iniciativa de la Fiscalía en lo relativo al supuesto fáctico y que, respecto de la atribución jurídica el control material, es excepcional, como cuando se vulnera la tipicidad ola legalidad en un allanamiento o en un preacuerdo o en el juicio, cuando el error en el nomen iuris lesiona los derechos y garantías de las partes o de los intervinientes (Corte Suprema de Justicia, Sentencia de octubre 16 de 2013).

Este argumento respalda la postura que aquí se adopta, en la medida en que el juez de control de garantías de ninguna manera puede convertirse en un simple espectador, máxime cuando se trata de velar por el respeto a la determinación como integrante del principio de legalidad, bien sea en un proceso ordinario o abreviado, pues, es a partir de la imputación que el indiciado es vinculado formalmente al proceso penal y desde ese momento surgen para él un conglomerado de derechos que deben ser garantizados no de manera puramente formal, sino material. En otras palabras: aunque la imputación es de carácter provisional, ha de ser fáctica, circunstanciada y jurídica, "pero íntegra en relación con el tipo objetivo y subjetivo" (Sandoval y Villar, 2013, p. 83). 
Postura similar es la adoptada por Toro (2012), cuando señala que la conducta que se va a atribuir al procesado debe adecuarse al tipo penal, tanto desde la estructura del tipo objetivo como la del tipo subjetivo, para lo cual debe compararse la conducta con la individualización típica, si lo que se quiere es un "acto de imputación con pretensiones de validez" (p. 200). Es cierto que al ser la Fiscalía la titular de la acción penal se enerva toda posibilidad de que el juez desconozca la imputación fáctica que se hace en la respectiva audiencia preliminar, y respecto de las actuaciones que se surtan con posterioridad no existe tal limitación, pues la intervención del juez debe ser activa, en procura del respeto de las garantías de las partes e intervinientes, ejerciendo de este modo y como lo ha definido la Corte Suprema de Justicia, un "control jurisdiccional material", que es producto de un deber de origen constitucional, "específicamente en lo que atañe a la estricta tipicidad" (Sentencia de octubre 16 de 2013).

Es de resaltar que la Corte Constitucional también ha hecho alusión al deber de la Fiscalía de acatar, en sus actuaciones, los postulados de legalidad y taxatividad. Fue así como, en decisión de constitucionalidad, al declarar exequible el numeral $2^{\circ}$ del artículo 350 de la Ley 906 de 2004, señaló al respecto que la facultad de la Fiscalía de tipificar la conducta en los eventos de allanamiento o preacuerdos no significa que pueda violarse la garantía constitucional de la legalidad, que debe corresponderse con el marco fáctico real que motiva la investigación penal (Sentencia C-1260 de 2005). Además, en la decisión de la Corte Suprema de Justicia a la cual se ha hecho referencia, y con fundamento en el citado precedente constitucional, aquella colegiatura fijó su criterio en torno al control material por parte del juez en los siguientes términos: “[e]xcepcionalmente el juez debe ejercer control material para preservar las garantías de las partes e intervinientes en los procesos penales (ordinarios o abreviados)" (Sentencia de octubre 16 de 2013).

Esa corporación, incluso con antelación a dicho pronunciamiento, había indicado como regla general que la acusación del fiscal en los procesos regidos por las disposiciones de la Ley 906 de 2004 no podía ser controvertida; sin embargo, admitió algunas excepciones al plantear, especialmente, el caso que se presenta cuando la adecuación típica que la Fiscalía hace de los hechos comporta una lesión manifiesta a las garantías fundamentales (Corte Suprema de Justicia, auto de mayo 16 de 2007). En otra ocasión, sostuvo que si la adecuación típica lesiona o rompe el principio de legalidad, ello habilita al juez para 
intervenir, pues la admisión de responsabilidad es formal por la violación de derechos y garantías superiores (Corte Suprema de Justicia, Sala de Casación Penal, Sentencia de febrero 6 de 2013).

Así las cosas, se puede concluir que, si el juez de conocimiento y solo por vía excepcional está facultado para realizar un control material a la acusación dentro de unas pautas de razonabilidad jurídica, situación análoga podría predicarse respecto al juez de control de garantías y, concretamente, en lo atinente a la imputación, pues es a partir de dicho acto de vinculación que surgen derechos para el imputado, motivo por el cual no es suficiente y en garantía del principio de taxatividad, que únicamente se autorice un control respecto de la acusación, en la medida en que, se insiste, el mismo debe hacerse extensivo a la imputación jurídica.

Por estas razones, autores como Rojas (2010) defienden que más allá de considerar a la imputación como un simple acto de comunicación deben analizarse los efectos globales que dicho acto procesal tiene sobre los derechos fundamentales de los asociados, $\mathrm{y}$, especialmente, su impacto sobre el derecho de defensa, puesto que si se prohíja una visión limitada como la que aquí se rechaza, "nos estaríamos quedando cortos respecto de los alcances mismos de la imputación, puesto que es allí donde se activa el derecho de defensa" (p. 204).

\section{El principio de congruencia entre la imputación y la acusación}

Es importante señalar que otro de los fundamentos por los cuales se considera necesario que exista un control en la imputación por parte del juez de control de garantías, es debido a que la congruencia en Colombia no se predica únicamente entre la acusación y la sentencia, sino, además, entre la imputación y la acusación, de tal manera que si se vislumbra incongruencia entre estos dos actos bien podría plantearse una nulidad. Tampoco puede soslayarse el hecho de que la acusación en todo caso debe hallarse acorde con el principio de determinación, siendo necesario, entonces, que se respete desde el mismo acto de vinculación del imputado al proceso penal. Téngase en cuenta que a través del Acto Legislativo 03 de 2002 se incorporó en nuestro país un sistema procesal penal con una marcada tendencia acusatoria (aunque sigue siendo mixto, como ya se dijo) y en el cual el principio de congruencia reviste una trascendencia bastante significativa en garantía del derecho de defensa. 
En torno a las características propias del postulado de la congruencia, la Corte Constitucional al estudiar la exequibilidad de los artículos 6 y 448 -parciales- de la Ley 906 de 2004 se refirió a ella indicando sus rasgos esenciales: (a) la congruencia orienta las relaciones entre la formulación de la acusación y la sentencia; (b) orienta asimismo el vínculo entre la formulación de la imputación y la acusación; (c) la acusación no puede incorporar hechos nuevos no imputados al procesado; (d) la valoración jurídica puede sufrir modificaciones, por el avance mismo de la labor investigativa (Sentencia C-025 de 2010). A través de dicho pronunciamiento, el máximo tribunal en materia constitucional fue enfático al resaltar que la aplicación del principio de congruencia opera también entre el acto de formulación de imputación y la audiencia de acusación, sin embargo, clarificó que tal armonía se predica única y exclusivamente en el aspecto fáctico, por lo que no resulta viable que la acusación comprenda hechos nuevos que no fueron objeto de imputación, es decir, respecto de los cuales el acusado no tendría la oportunidad de defenderse.

Ahora bien, atendiendo al principio de progresividad por el que se orienta el proceso penal, es factible que la denominación jurídica que se le atribuye a los hechos varíe entre la imputación y la acusación, sin que ello conlleve afectación de garantías fundamentales, pues no se olvide que como resultado de la labor investigativa bien podrían aparecer nuevos elementos de conocimiento que conducirían a variar la calificación jurídica. Precisamente, para formular una imputación se requiere una inferencia razonable de autoría o de participación, en tanto que, para la acusación, se exige un grado mayor de conocimiento denominado probabilidad de verdad, momento para el cual se cuenta con una investigación formal bastante perfeccionada que permitirá una comprensión mayor acerca de los hechos que serán materia de juzgamiento.

Ese organismo judicial consideró que se afectaría de manera ostensible el derecho de defensa en la hipótesis de no exigirse la aplicación del principio de congruencia entre la imputación de cargos y la formulación de acusación, haciendo claridad en el sentido de que la armonía que se predica es de orden puramente fáctico por lo que -en atención a la progresividad a la cual se ha hecho mención- la denominación jurídica de los hechos ostenta una naturaleza provisional y, en tal medida puede variar dentro de unos parámetros de razonabilidad y proporcionalidad. 
Lo cierto es que, en todo caso, una variación fáctica modifica sustancialmente la adecuación jurídica, en cuanto a que ciertos hechos podrían significar la configuración de una circunstancia o de otro delito especial agravado o atenuado; por esta razón, no parece tan sencillo que se pueda variar la calificación jurídica dejando inmutables la realidad fáctica en la imputación. Por ello, se encuentra que desde la imputación es muy difícil variar la adecuación jurídica sin modificar la realidad fáctica y que desde la misma imputación -con base en los hechos expuestos por el ente acusador- se presenta la obligación de la Fiscalía de realizar la adecuación jurídica de los hechos conforme a la ley y, cuando, el fiscal falla en dicha obligación, le compete al juez corregir para garantizar los derechos fundamentales del procesado y de las víctimas.

Recapitulando, debe decirse que la aludida corporación sostuvo que el artículo 448 de la Ley 906 de 2004, interpretado de conformidad con los artículos 29 y 31 superiores y $8^{\circ}$ de la Convención Americana sobre Derechos Humanos, conlleva el entendimiento de la congruencia como igualmente aplicable a la relación existente entre la imputación y la acusación. Incluso, la Corte Suprema de Justicia también se ha ocupado de analizar dicho aspecto y, en decisión reciente, señaló que la imputación fáctica debe ser simétrica con la acusación, y que el fiscal tiene la posibilidad de precisar las circunstancias del comportamiento, pero sin que pueda afectarse el núcleo fáctico fundamental de la acusación (Corte Suprema de Justicia, Sentencia de octubre 16 de 2013). En ese orden de ideas, ostenta una especial relevancia el principio de congruencia entre la imputación y la acusación y, si ello es así, surge la necesidad de que el juez de garantías intervenga desde aquella audiencia preliminar con la finalidad de que la adecuación típica que de los hechos realiza la Fiscalía, respete el principio de taxatividad como integrante del debido proceso plasmado en el artículo 29 de la Constitución Política.

\section{Conclusiones}

De conformidad con lo expuesto en este trabajo, se considera necesario que el juez de control de garantías realice un control material sobre la imputación jurídica llevada a cabo por la Fiscalía General de la Nación en la audiencia preliminar de formulación de imputación, porque con ello se evitan violaciones groseras al principio de legalidad, especialmente en lo concerniente al principio de determinación; además, porque esa es la mejor manera de proteger los 
derechos fundamentales de las víctimas a la verdad y a la justicia. Así, debe tenerse plena claridad sobre la potestad de que se encuentra investido el juez de control de garantías en el sentido de no convalidar la legalidad de la formulación de la imputación, si esta se halla en contradicción con el ordenamiento jurídico (Vanegas, 2008, p. 259).

Igualmente, el examen material que realice el juez de control de garantías sobre la correcta adecuación típica sería un filtro eficiente para evitar nulidades por violación a la taxatividad en la acusación, evitando, de esta manera, que el juez de conocimiento tenga que intervenir en la audiencia de formulación de acusación para sugerir un cambio en la calificación jurídica de los hechos, afectando, de esta forma, su imparcialidad y objetividad a la hora de afrontar el juicio; esta dificultad no se presentaría si el juez de control de garantías, desde la audiencia de formulación de imputación, corrige la calificación jurídica. También, este filtro permitiría evitar, como ocurre en algunos países de Europa, que se someta a una persona a un juicio sin suficiente soporte con grave desmedro a su buen nombre, con violación al debido proceso y afectando la economía y eficiencia de la administración de justicia.

Así mismo, debe indicarse que la implementación de un control material por parte del juez de control de garantías sobre la calificación jurídica de la conducta desde la formulación de imputación, no afectaría la esencia de un sistema procesal penal adversarial, porque no sería el mismo juez de conocimiento el que interviene para corregir la calificación jurídica, sino un juez ajeno al juicio y previo al mismo, quien subsanaría en buen tiempo y para bien del proceso un asunto que puede ocasionar nulidad por vulneración al principio de legalidad, y además, claro está, puede afectar el derecho de defensa del imputado -pues no es lo mismo defenderse de una imputación por unas lesiones personales, que por una tentativa de homicidio-, y los derechos de las víctimas a la verdad y a la justicia como se pudo evidenciar a lo largo de este escrito.

Por último, un control material a cargo del juez de control de garantías sobre la calificación jurídica realizada por la Fiscalía permitiría un mayor grado de lealtad procesal entre las partes, abonando el terreno para figuras como los preacuerdos, el allanamiento, 
el principio de oportunidad, la acusación o la preclusión. Así las cosas, bien establecido el marco legal de la pretensión punitiva de la Fiscalía, queda claro para las partes y los intervinientes cuál es el escenario para negociar las rebajas de pena a las que el reo puede acceder haciendo prevalecer el derecho a la igualdad frente a la ley y, añádase, la transparencia respecto de los derechos de las víctimas. La función del juez de control de garantías se inscribe, pues, dentro de la salvaguarda de los contenidos constitucionales del proceso penal; es por ello que la única postura constitucionalmente válida sobre su rol implica la posibilidad de controlar los aspectos materiales de la imputación (Rojas, 2010, p. 206), y esto también tiene soporte Constitucional en el artículo 230 superior en el cual, con toda claridad, se establece que los jueces están sometidos al imperio de la ley, por lo que no pueden ser meros observadores cuando se le da a una situación fáctica una denominación jurídica contraria a lo establecido por la ley penal para generar, de esta manera, un deber de actuar en aras de hacer cumplir la ley y la Constitución.

De igual forma, la revisión del derecho comparado en materia de principio acusatorio permitió establecer que uno de sus nortes es la separación funcional entre las actividades de acusación y juzgamiento, y, a partir de dicho postulado, se estructura el deber de la Fiscalía de ejercer la persecución penal ciñéndose al respeto de las garantías fundamentales de las partes y de los intervinientes. De esta manera, en el ordenamiento procesal penal colombiano se tiene que a la Fiscalía, en tanto titular de la acción penal, no solamente le está permitido -sino que tiene el deber legal de-imputar jurídicamente un determinado marco fáctico a una persona sometida a potestad punitiva. No obstante, este deber no se traduce en que la Fiscalía actúe en un contexto carente de vigilancia legal y constitucional, en el que pueda desconocer groseramente el marco fáctico esencial de la imputación, pues, si de manera flagrante se vulnera el principio de taxatividad o de determinación, el juez de control de garantías puede efectuar el control material a la tipificación realizada por el titular de la acción penal, como forma de garantizar los derechos fundamentales implicados en la actuación.

Es más: si la Fiscalía tiene la obligación de realizar una adecuación jurídica de los hechos imputados conforme a la ley, pero no lo hace, el juez, como director del proceso, lo debe llevar a cabo en atención a que tiene ese deber legal y no puede emitir una resolución en un asunto que resulte contraria a derecho y, por ende, ilegal; por ello, 
en este trabajo se propone que desde la imputación, el juez de control de garantías debe tener la posibilidad de modificar la calificación jurídica o, por lo menos, de informar al imputado que el juicio podría incluir otras conductas que no se encuentran contenidas en la imputación, como ocurre en Costa Rica, para que el imputado pueda preparar mejor su defensa. Esto posibilitaría evitar que los jueces de conocimiento tengan que inmiscuirse en la calificación jurídica en la audiencia de acusación, pues el debate sobre ella se daría en la formulación de imputación y permitiría, como es obvio, a las partes y a los intervinientes, tener clara la pretensión de la Fiscalía, amén del marco legal para negociar, allanarse o defenderse en juicio.

En fin, dígase para poner punto final a este escrito, que el proceso penal no es solamente una sucesión de pasos que permitan establecer la responsabilidad penal de una persona, sino que es un decurso que en sí mismo ha de garantizar los derechos fundamentales de los asociados que participen o sean sujetos pasivos de la acción penal, y esa es la razón esencial para proclamar que el juez de control de garantías está investido del poder para controlar la imputación jurídica en los casos aquí reseñados.

\section{Referencias}

Alvarado, A. (2006). La imparcialidad judicial. En La ciencia del Derecho procesal constitucional, Estudios en homenaje a Héctor Fix-Zamudio en sus cincuenta años como investigador del Derecho (pp. 143-158). Buenos Aires: Marcial Pons Ediciones de Argentina.

Amnistía Internacional. (2008). Alemania: La lucha contra la impunidad a través de la jurisdicción universal. Londres: Amnesty International Publications.

Aragón, M. (2003). Breve curso de Derecho Procesal Penal. Oaxaca: Independiente.

Arango, M. I. (2010). A propósito del papel del juez de control de garantías en la audiencia de formulación de imputación. Nuevo Foro Penal (6)75, 231-242.

Auto 27.218 (2007, mayo 16). Casación. M. P. Yesid Ramírez Bastidas. Sala de Casación Penal, Corte Suprema de Justicia.

Auto 33301 (2010, marzo 11). Apelación. M. P. Alfredo Gómez Quintero. Sala de Casación Penal, Corte Suprema de Justicia.

Auto 42.357 (2014, 28 mayo). Apelación. Magistrado Ponente: Eugenio Fernández Carlier. Corte Suprema de Justicia. Sala de Casación Penal. 
Barbosa, G. (2005). Estructura del proceso penal. Aproximación al proceso penal colombiano. En Reflexiones sobre el nuevo sistema procesal penal. Los grandes desafíos del juez penal colombiano (pp. 67-110) Bogotá: Consejo Superior de la Judicatura, Escuela Judicial “Rodrigo Lara Bonilla".

Bernal, J. y Montealegre, E. (2013). El Proceso Penal (Tomo I). Fundamentos constitucionales y teoría general. 6 ed. Bogotá: Universidad Externado de Colombia.

Bernal, J. y Montealegre, E. (2013). El Proceso Penal (Tomo II). Estructura y garantías procesales. 6 ed. Bogotá, Colombia: Universidad Externado de Colombia.

Bovino, A. (1997). El principio acusatorio como garantía de imparcialidad en el proceso de reforma de la administración de justicia penal. Conferencia pronunciada en el Primer Congreso de la Asociación de Ciencias Penales de Costa Rica en San José, el 30 de mayo de 1997. Recuperado de https: / / ensaiosjuridicos.files.wordpress.com/2013/04/el-principioacusatorio-como-garantia-de-imparcialidad-alb.pdf.

Cafferata, J. I. (1984). Derechos individuales y proceso penal. Colección opúsculos de Derecho penal y Criminología, No. 4. Córdoba: Marcos Lerner Editora Córdoba.

Cafferata, J. I. (2000). Proceso penal y Derechos Humanos. La influencia de la normativa supranacional sobre derechos humanos de nivel constitucional en el proceso penal argentino. Buenos Aires: Editores del Puerto.

Cafferata, J. I. et al. (2012). Manual de Derecho Procesal Penal. Buenos Aires: Advocatus.

Carbonell, M. (2008). La reforma constitucional en materia penal: luces y sombras (pp. 59-94). Recuperado de http://biblio.juridicas.unam.mx/ libros $/ 7 / 3069 / 8$.pdf.

Caso, G. (2003). El sistema procesal penal italiano (ventajas y dificultades). En Dikaion 17 (12). Recuperado de http://www.redalyc.org/articulo. oa?id=72001203.

Castro-Jofré, J. (2005). Los principios fundamentales del sistema acusatorio. Revista de Derecho de la Pontificia Universidad Católica de Valparaíso (vol. XXVI) 343-349. Recuperado de http://www.redalyc.org/articulo. oa?id=173619921018.

Constitución Política (1991). Congreso de la República de Colombia. Recuperado de http:/ / www.secretariasenado.gov.co/index.php/leyes -y-antecedentes/ constitucion-y-sus-reformas. 
Contreras, J. R. (2011). Derecho procesal penal en el sistema acusatorio. Ciudad de México: Centro de Estudios Sobre la Enseñanza y el Aprendizaje del Derecho.

Córdova del Valle, F. (2011). Investigación. Primera fase procesal del proceso penal acusatorio y oral. En El nuevo sistema de justicia penal acusatorio, desde la perspectiva constitucional (pp. 291-311). Ciudad de México: Consejo de la Judicatura Federal-Poder Judicial de la Federación.

Estados Unidos Mexicanos. Constitución Política de los Estados Unidos Mexicanos (1917). Recuperado de http://www.juridicas.unam.mx/ infjur/leg/conshist/pdf/1917.pdf.

Estados Unidos Mexicanos. Código Nacional de Procedimientos Penales (2014), vigente al 28 julio de 2015 Recuperado de http://www. diputados.gob.mx/LeyesBiblio/pdf/CNPP_291214.pdf

Estrasburgo. Directiva 29 de 2012. Por la que se establecen normas mínimas sobre los derechos, el apoyo y la protección de las víctimas de delitos, y por la que se sustituye la Decisión marco 2001/220/JAI del Consejo. Recuperada de https://www.boe.es/doue/2012/315/L00057-00073. pdf

Espinoza, W. (2009). Alcances doctrinarios sobre el sistema acusatorio. Derecho y cambio social, revista on-line (19), VI. Recuperado de http: / / www. derechoycambiosocial.com/revista019/principio\%20acusatorio.htm.

Ferrajoli, L. (2001). Derecho y razón. Teoría del garantismo penal. Madrid: Trotta.

García, S. A. (2011). El procedimiento penal. En El nuevo sistema de justicia penal acusatorio, desde la perspectiva constitucional (pp. 269-289) Ciudad de México: Consejo de la Judicatura Federal-Poder Judicial de la Federación.

García, E. y Ávila, L. (2009). Aplicación del sistemismo a cuestiones específicas del proceso penal mexicano. El tema del principio acusatorio. Revista de Derecho (32) 97-115.

Gobierno de Chile. Ministerio de Justicia. (2005). Guía práctica de la reforma procesal penal. Santiago de Chile: Unidad Coordinadora de la Reforma Procesal Penal.

Gómez, J. L. (1997). La instrucción del proceso penal por el ministerio fiscal: aspectos estructurales a la luz del Derecho comparado. Revista Peruana de Derecho Procesal (1), 335-358.

Gómez, J. L. (2003). El Tribunal Penal Internacional: investigación y acusación. Valencia, España: Tirant lo Blanch. 
Gómez, J. L. (2007). La reforma estructural del proceso penal y la elección del modelo a seguir. Recuperado de https://www.unifr.ch/ddp1/ derechopenal/articulos / a_20080521_92.pdf.

Guerrero, Ó. J. (2005). El Juez de control de garantías. En Reflexiones sobre el nuevo sistema procesal penal. Los grandes desafíos del juez penal colombiano (pp. 163-214) Bogotá: Consejo Superior de la Judicatura, Escuela Judicial "Rodrigo Lara Bonilla".

Guerrero, Ó. J. (2006). El difícil encuentro entre el proceso penal anglosajón y el proceso continental. En Biblioteca Jurídica Virtual del Instituto de Investigaciones Jurídicas de la UNAM. Anuario de Derecho Constitucional Latinoamericano pp. 1047-1069. Recuperado de http:/ / www.juridicas. unam.mx/publica/librev/ rev/dconstla/cont/2006.2/pr/pr20.pdf.

González, D. (2007). Derecho Procesal penal costarricense (Tomo II). El procedimiento preparatorio. San José de Costa Rica: Asociación de Ciencias Penales de Costa Rica.

Haas, E. (2006). Las garantías constitucionales en el procedimiento penal alemán. Justicia Constitucional. Revista de jurisprudencia y doctrina (3), 191-212.

Horvitz, M. I. y López, J. (2002). Derecho Procesal Penal chileno (Tomo I). Chile: Santiago, Editorial Jurídica de Chile.

Houed, M. A. (2005). El proceso penal en Costa Rica. Recuperado de https: / / d3gqux9s10z33u.cloudfront.net/AA / AT/gambillingonjustice-com/ downloads/215003/dp-ppenal_costarica.pdf.

Jaén, M. (2008). Acusación e investigación en el sistema procesal penal. Revista Diálogos de Saberes, pp. 195-217.

Ley 906 de 2004. Por la cual se expide el Código de Procedimiento Penal. Diario Oficial, No. 45668. Congreso de la República de Colombia, septiembre de 2004. Recuperado de http:/ / www.secretariasenado.gov. co/senado/basedoc/ley_0906_2004.html

López, J. (2012). Tratado de Derecho Procesal Penal (Tomo I). 5 ed. Navarra: Aranzadi.

Luna, J. N. (2011). Introducción y características generales del nuevo sistema de justicia penal. En El nuevo sistema de justicia penal acusatorio, desde la perspectiva constitucional (pp. 23-50) Ciudad de México: Consejo de la Judicatura Federal-Poder Judicial de la Federación.

Maciel, R. (2003). El procedimiento abreviado en el proceso penal continental europeo. Revista Jurídica del Centro de Estudiantes de Derecho de la Universidad Católica de Asunción, CEDUC (12) pp. 423-465.

140 Cuadernos de Derecho Penal, ISSN: 2027-1743 / 2500-526x [En línea], julio-diciembre de 2015 
Maier, J. B. J. (1989). Derecho Procesal Penal Argentino (T. I), Vol. B. Buenos Aires, Argentina: Hammurabi.

Martínez, J. L. (2011). El sistema acusatorio en los Códigos de Procedimientos Penales en México. En El nuevo sistema de justicia penal acusatorio, desde la perspectiva constitucional (pp. 397-426). Ciudad de México: Consejo de la Judicatura Federal-Poder Judicial de la Federación.

Mera, J. (2002). Discrecionalidad del Ministerio Público, calificación jurídica y control judicial. En Colección Informes de Investigación (12), 4, pp. 235258. Santiago: Centro de Investigaciones Jurídicas de la Facultad de Derecho de la Universidad Diego Portales.

Meza, E. (2009). Principio acusatorio y de oralidad en los juicios relativos a los delitos de delincuencia organizada. Revista del Instituto de la Judicatura Federal (27), 195-213.

Montero, J. (1994). La garantía procesal penal y el principio acusatorio. Recuperado de http: / / biblio.juridicas.unam.mx/libros / 2/836/28.pdf.

Obando, S. W. (1999). El sistema acusatorio y el proyecto de reforma procesal penal. Revista de derecho (10) 31-39. Recuperado de http: / / mingaonline. uach.cl/ scielo.php?pid=S0718-09501999000100006\&script=sci_arttext.

Pinto, F. J. (1988). El nuevo Código de Proceso Penal portugués. Jueces para la Democracia (5) 59-62. Recuperado de http: / / www.juecesdemocracia. es / revista / revista\%2005\%20diciembre\%201988.pdf.

Piersack vs. Bélgica. (1982). Demanda No. 8692/1979. Tribunal Europeo de Derechos Humanos. Recuperado de http://portal.uclm.es/descargas/ idp_docs / jurisprudencia / caso $\% 20$ piersack $\% 20$ contra $\% 20$ belgica $\% 20-\% 20$ derecho $\% 20 \mathrm{a} \% 20 \mathrm{un} \% 20$ proceso $\% 20$ independiente $\% 20 \mathrm{e} \% 20 \mathrm{imparcial}$.pdf

Reino de España. Ley de Enjuiciamiento Criminal Española (1882). Real Decreto de 14 de septiembre de 1882, Ministerio de Gracia y Justicia. Recuperado de https://www.boe.es/buscar/pdf/1882/BOE-A-18826036-consolidado.pdf.

República Argentina. Código Procesal Penal de la Nación Argentina (1991). Ley 23984. Recuperado de http: / / www.infojus.gob.ar/docs-f/codigo/ Codigo_Procesal_Penal_de_la_Nacion.pdf

República Argentina. Constitución Politica de la Nación Argentina (1994). Recuperado de http://www.cepal.org/oig/doc/argentinaconstitucionpolitica.pdf

República de Chile. Constitución Politica de la República de Chile (1980). Recuperado de https://www.camara.cl/camara/media/docs/constitucion_politica.pdf. 
República de Chile. Ley Orgánica Constitucional del Ministerio Público (1999). Ley 19.640 de 15 de octubre de 1999. Recuperado de http://www. leychile.cl/Navegar?idNorma=145437.

República de Chile. Código Procesal Penal de la República de Chile (2000). Ley no. 19.696. Recuperado de http://www.leychile.cl/ Navegar?idNorma $=176595$

República de Costa Rica. Código Procesal Penal (1996). Ley 7594, Recuperado de http: / / www.wipo.int/ wipolex/es/text.jsp?file_id=220086

República Italiana. Codice di Procedura Penale (1988), DPR 22 settembre 1988, n. 447. Recuperado de http://www.polpenuil.it/attachments/048_ codice_di_procedura_penale.pdf

República del Perú. Constitución Política del Perú (1993). Recuperado de http:/ / www.pcm.gob.pe/wp-content/uploads/2013/09/Constitucion-Pol\%C3\%ADtica-del-Peru-1993.pdf.

República del Perú. Código Procesal Penal (2004). Ley 28269 de cuatro de julio, Perú. Recuperado de http://www.justiciaviva.org.pe/nuevos/ cpp-dec957.pdf

República del Perú. Queja No 1678 (2007, abril 13). Sala Penal Permanente de la Corte Suprema de la República del Perú.

República del Perú. Manuel Enrique Sandoval Umbert. (2006, marzo 13). Sentencia. Tribunal Constitucional del Perú. Recuperado de http:// www.tc.gob.pe/jurisprudencia/2006/ 02005-2006-HC.html.

República Portuguesa. Código de Processo penal (1987). DL No. 78/87, de 17 de Fevereiro. Recuperado de http://www.pgdlisboa.pt/leis/lei_ mostra_articulado.php?nid=199\&tabela=leis.

Rodríguez, M. (2013). Sistema acusatorio de justicia penal y principio de obligatoriedad de la acción penal. Revista de Derecho de la Pontificia Universidad Católica de Valparaíso. Volumen XL, Primer Semestre, pp. 643-686.

Rojas, L. (2010). Las cargas argumentativas en la imputación: un comentario a propósito del caso de Carlos Reina y la respuesta dada por la Corte Suprema de Justicia colombiana al respecto. Nuevo Foro Penal (74) 201-208.

Rúa, R. J. (2009). El principio acusatorio y la necesidad de una reforma legislativa. Ponencia presentada en el I Congreso Internacional y II Nacional del Sistema Penal celebrado en Buenos Aires en septiembre de 2009. Buenos Aires: Argentina, Sistema Argentino de Información Jurídica. Recuperado de http://www.infojus.gob.ar/doctrina/dacc090075-ruaprincipio_acusatorio_necesidad_una.htm. 
Sandoval, J. y Del Villar, D. D. (2013). Responsabilidad penal y detención preventiva. El proceso penal en Colombia, Ley 906 de 2004. Bogotá: Grupo Editorial Ibáñez.

Sentencia C-739 (2000, junio 22). Demanda de inconstitucionalidad. M. P. Fabio Morón Díaz. Corte Constitucional.

Sentencia C-228 (2002, abril 3). Demanda de inconstitucionalidad. M. P. Manuel José Cepeda Espinosa y Eduardo Montealegre Lynett. Corte Constitucional.

Sentencia C-591 (2005, junio 9). Demanda de inconstitucionalidad. M. P. Clara Inés Vargas Hernández. Corte Constitucional.

Sentencia C-1260 (2005, diciembre 5). Demanda de inconstitucionalidad. M. P. Clara Inés Vargas Hernández. Corte Constitucional.

Sentencia C-209 (2007, marzo 21). Demanda de inconstitucionalidad. M. P. José Cepeda Espinosa. Corte Constitucional.

Sentencia C-025 (2010, enero 27). Demanda de inconstitucionalidad Expediente D-7858. M. P. Humberto Antonio Sierra Porto. Corte Constitucional.

Sentencia C-059 (2010, febrero 3). Demanda de inconstitucionalidad. M. P. Humberto Antonio Sierra Porto. Bogotá. 2010. Corte Constitucional.

Sentencia C-144 (2010, marzo 3). Demanda de inconstitucionalidad. M. P. Juan Carlos Henao Pérez. Corte Constitucional.

Sentencia C-260 (2011, abril 6). Demanda de inconstitucionalidad. M. P. Jorge Iván Palacio Palacio, Corte Constitucional.

Sentencia 27.759 (2007, septiembre 12). Recurso de Casación. M. P. Alfredo Gómez Quintero. Corte Suprema de Justicia. Sala de Casación Penal.

Sentencia 28.432 (2007, diciembre 5). Recurso de Casación. M. P. María del Rosario González Muñoz. Corte Suprema de Justicia. Sala de Casación Penal.

Sentencia 39.892 (2013, febrero 6). Recurso de Casación. M. P. José Luis Barceló. 2013. Corte Suprema de Justicia. Sala de Casación Penal, Colombia.

Sentencia 36.842 (2013, noviembre 27). Recurso de Casación. M. P. María del Rosario González Muñoz. Corte Suprema de Justicia. Sala de Casación Penal.

Sentencia 39.886 (2013, octubre 16). Recurso de Casación. M. P. José Leonidas Bustos Martínez. Corte Suprema de Justicia. Sala de Casación Penal. 
Sentencia 39.886. (2014, mayo 20). Acción de tutela. M. P. Eugenio Fernández Carlier. Corte Suprema de Justicia. Sala de Casación Penal.

Sintura, F. J. (2005). Evolución del sistema acusatorio en Colombia. En Bernate, F. A.A. (Eds.) Sistema penal acusatorio (pp. 19-34). Bogotá: Biblioteca Jurídica Dike.

Toro, Ó. A. (2012). De la imputación penal sustancial a la imputación penal procesal válida. Un diálogo de doble vía. Criterio Jurídico Garantista (6) 188-203.

Urbano, J. J. (2013). El control de la acusación. Bogotá: Universidad Externado de Colombia.

Vanegas, P. L. La imputación. (2008). En Posada, J. J. y Jaramillo, J. G. (compiladores). Reflexiones sobre el sistema acusatorio. Una visión desde la práctica judicial (pp. 233-267). Bogotá: Librería Jurídica Sánchez.

Zuluaga, J. E. (2007). Comentarios a la función de control de garantías. A propósito de la Ley 906 de 2004 o "Sistema procesal penal acusatorio". Co-herencia (vol. 6, 4)133-165. 